\title{
TINJAUAN ATAS PENGAKUAN \\ DAN PENGUKURAN ASET TETAP PADA WIN'S HOTEL
}

TUGAS AKHIR

Oleh :

AMANDA DANIELA

NPM : 11900007

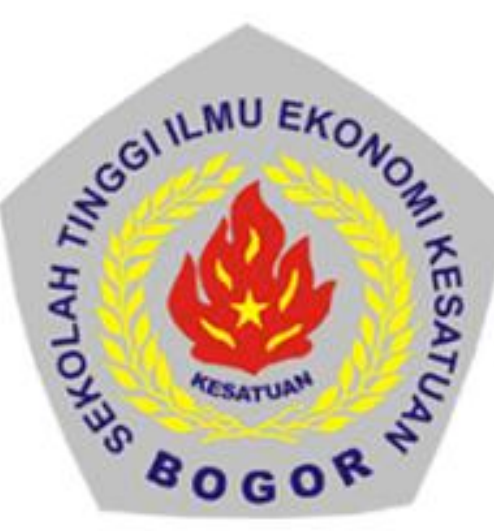

PROGRAM DIPLOMA III AKUNTANSI

SEKOLAH TINGGI ILMU EKONOMI KESATUAN

BOGOR

2014 


\title{
TINJAUAN ATAS PENGAKUAN DAN PENGUKURAN ASET TETAP PADA WIN'S HOTEL
}

\author{
Tugas Akhir \\ sebagai salah satu syarat untuk memperoleh \\ gelar Ahli Madya pada Program Studi Akuntansi \\ Sekolah Tinggi Ilmu Ekonomi Kesatuan
}

Oleh:

AMANDA DANIELA

NRP : 11900007

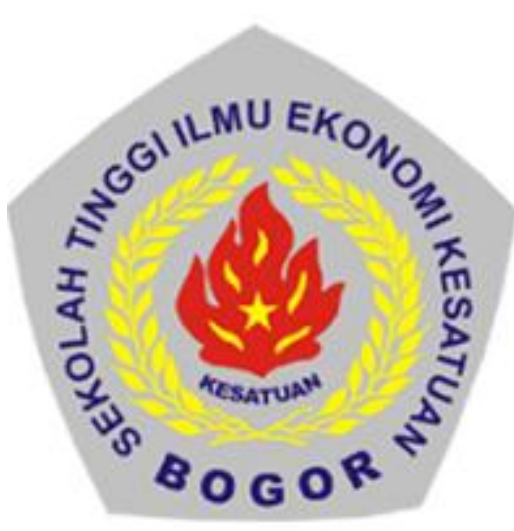

\section{PROGRAM DIPLOMA III AKUNTANSI \\ SEKOLAH TINGGI ILMU EKONOMI KESATUAN BOGOR \\ 2014}




\section{TINJAUAN ATAS PENGAKUAN DAN PENGUKURAN ASET TETAP PADA WIN'S HOTEL}

TUGAS AKHIR

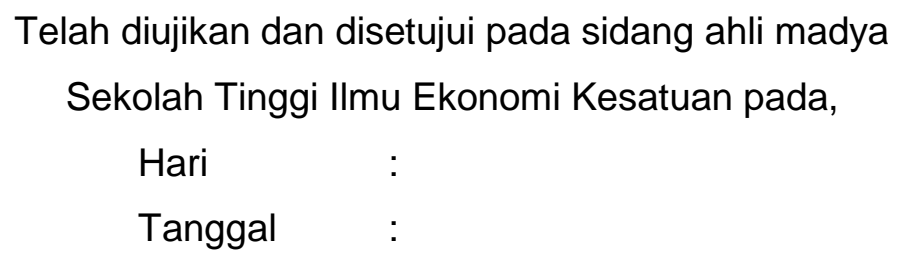

Mengetahui,

Ketua

Ketua Program Studi Akuntansi

Ir. Nusa Muktiaji, M.M,

Yayuk Nurjanah, SE., M.Ak, 


\title{
TINJAUAN ATAS PENGAKUAN PEROLEHAN DAN PENYUSUTAN ASET TETAP PADA WIN'S HOTEL
}

\section{TUGAS AKHIR}

Telah disetujui oleh Pembimbing

\author{
Yayuk Nurjanah, SE., M.Ak, \\ Telah diujikan pada siding Ahli Madya dan \\ Dinyatakan LULUS pada tanggal \\ seperti tertera di bawah ini
}

Bogor, 23 September 2014

Penguji I

Penguji II

Siti Ita Rosita, SE., MM., SAS.

Sutarti, SE., MM., SAS. 


\begin{abstract}
ABSTRAK
AMANDA DANIELA. NRP 11900007. Tinjauan Atas Pengakuan dan Pengukuran Aset Tetap pada Win's Hotel. Dibawah bimbingan YAYUK NURJANAH, SE, M.Ak.

Win's Hotel adalah perusahaan jasa di bidang perhotelan yang didirikan pada tahun 2011 dengan konsep 'Low Budget Hotel' yang dapat menjangkau kalangan menengah ke bawah. Pengelolaan aset tetap yang dimiliki oleh Win's Hotel sangat penting dalam menjaga kelancaran aktivitas hotel. Pencatatan, pengakuan dan penyusutan aset hotel menentukan keputusan manajemen dalam melakukan investasi aset kembali.

Tujuan peninjauan ini adalah untuk mengetahui pengakuan atas perolehan dan penyusutan aset tetap yang dimiliki Win's Hotel, metode penyusutan yang digunakan Win's Hotel dalam menghitung harga perolehan dan beban penyusutan serta proses penyajiannya di dalam laporan posisi keuangan. Adapun lokasi tempat dilakukannya peninjauan adalah di Win's Hotel, Jl. H. Achmad Adnawijaya No. 11-D, Tegalgundil, Bogor Utara.

Dari hasil tinjauan diketahui bahwa pengakuan aset tetap pada Win's Hotel adalah sebesar harga pembelian, dan biaya lainnya yang terkait sampai aset tersebut siap untuk digunakan. Metode penyusutan aset yang digunakan adalah metode garis lurus, dan penyajian aset dalam laporan posisi keuangan dikelompokkan sesuai dengan fungsi asetnya.

Setelah melakukan peninjauan, penyusun memberikan saran kepada Win's Hotel agar biaya reparasi atau perbaikan aset yang berjumlah besar dan menambah umur manfaat aset dapat diakui sebagai penambah harga perolehan, penyusutan dihitung secara proporsional berdasarkan umur penggunaannya, dan setiap tahun diharapkan perusahaan dapat mereview sisa umur manfaat aset berdasarkan kondisi fisik asetnya.
\end{abstract}

Keyword : Aset Tetap Hotel, Metode Penyusutan, Penyusutan Aset. 


\section{KATA PENGANTAR}

Puji dan syukur penyusun panjatkan kepada Tuhan Yang Maha Esa karena dengan rahmat dan karunia-Nya tugas, penyusun mampu menyelesaikan Tugas Akhir yang berjudul "Tinjauan Atas Pengakuan dan Pengukuran Aset Tetap pada Win's Hotel”. Tugas Akhir ini dikerjakan demi memenuhi salah satu syarat guna memperoleh gelar Ahli Madya Jurusan Akuntansi pada Sekolah Tinggi Ilmu Ekonomi Kesatuan Bogor.

Penyusun menyadari bahwa tugas akhir ini bukanlah tujuan akhir dari belajar, karena belajar adalah sesuatu yang tidak terbatas. Penyusun juda menyadari sepenuhnya bahwa tugas akhir ini masih jauh dari kesempurnaan baik isi, bahasa serta penulisannya. Hal ini disebabkan keterbatasan penyusun dari segi ilmu pengetahuan, bahan atau data, dana dan waktu sehingga kritik dan saran yang membangun sangat penyusun harapkan demi kesempurnaan tugas akhir ini.

Terselesaikannya tugas akhir ini tentunya tak lepas dari dorongan dan uluran tangan berbagai pihak. Oleh karena itu, penulis mengucapkan terima kasih kepada :

1. Tuhan Yesus Kristus, yang telah menyertai dan memberkati sehingga tugas akhir ini dapat terselesaikan dengan baik.

2. Bapak Nusa Muktiadji, Ir, MM., selaku Ketua STIE Kesatuan Bogor.

3. Ibu Siti Ita Rosita, SE., selaku Ketua Program Studi Akuntansi Strata 1 STIE Kesatuan Bogor.

4. Ibu Yayuk Nurjanah, SE, M.Ak, selaku Ketua Program Studi Diploma 3 STIE Kesatuan Bogor dan Dosen Pembimbing yang telah banyak 
meluangkan waktu untuk membimbing penyusun hingga terselesaikannya tugas akhir ini.

5. Ibu Husnul Toyibah, S, Sos., selaku Kepala UPT Perpustakaan STIE Kesatuan Bogor yang telah menyediakan bahan literatur dan referensi bagi penyusun dalam menyelesaikan tugas akhir ini.

6. Bapak dan Ibu Dosen serta Staff Karyawan STIE Kesatuan Bogor yang telah banyak membantu selama masa perkuliahan berlangsung serta memberikan ilmu pengetahuan serta fasilitas yang berkenaan dengan terselesaikannya tugas akhir ini.

7. Staff Karyawan Win's Hotel yang dengan senang hati membantu penyusun dalam mengumpulkan data dan melakukan observasi.

8. Untuk keluarga tercinta, Papa, Kakak, dan Adik-adik saya tersayang yang telah mendukung dan memberikan semangat untuk saya dalam menyelesaikan tugas akhir ini.

9. Serta semua pihak yang telah membantu dalam penyelesaian tugas akhir ini seperti teman-teman selama menjalankan perkuliahan D3 Akuntansi STIE Kesatuan Bogor dan banyak pihak yang tidak dapat saya sebutkan satu per satu.

Semoga Tuhan Yang Maha Esa membalas kebaikan dan ketulusan semua pihak yang telah membantu menyelesaikan tugas akhir ini dengan melimpahkan rahmat dan karunia-Nya. Semoga karya penelitian tugas akhir ini dapat memberikan manfaat dan kebaikan bagi banyak pihak.

Bogor, 19 September 2014

Penyusun

(Amanda Daniela) 


\section{DAFTAR TABEL}

Nomor

Teks

Halaman

3.1 Beban Penyusutan Bangunan per Tahun....................................... 50

3.2 Beban Penyusutan Bangunan per Tahun..................................... 51

3.3 Beban Penyusutan Kendaraan per Tahun .................................... 53

3.4 Beban Penyusutan Kendaraan per Tahun ................................... 54

3.5 Beban Penyusutan Peralatan Kantor per Tahun ............................ 56

3.6 Beban Penyusutan Peralatan Kantor per Tahun .............................. 59

3.7 Beban Penyusutan Peralatan Hotel-Elektronik per Tahun.................. 62

3.8 Beban Penyusutan Peralatan Hotel-Elektronik per Tahun................. 66

3.9 Beban Penyusutan Peralatan Hotel-Perabot per Tahun .................... 67

3.10 Beban Penyusutan Peralatan Hotel-Perabot per Tahun..................... 69

3.11 Beban Penyusutan Peralatan Hotel-Kain per Tahun ........................ 71

3.12 Beban Penyusutan Peralatan Hotel-Kain per Tahun ........................ 74 


\section{BAB I \\ PENDAHULUAN}

\subsection{Latar Belakang}

Menurut website resmi Kota Bogor pertumbuhan ekonomi Kota Bogor terus mengalami peningkatan dari tahun ke tahun. Di dalam laju pertumbuhan ekonomi Kota Bogor, terdapat pertumbuhan nilai investasi. Diperkirakan untuk tahun 2014 nilai investasi di Kota Bogor diprediksi dapat mengalami kenaikan sampai mencapai nilai Rp 10,4 triliun. Sementara pertumbuhan ekonomi tahun 2014 diperkirakan dapat melaju dengan angka 6,26\%. Perdagangan, hotel dan restoran merupakan sektor bisnis yang berkontribusi sangat besar pada pertumbuhan ekonomi Kota Bogor.

Perkembangan bisnis perhotelan di Kota Bogor, masih memiliki potensi besar. Tercatat hingga saat ini terdapat 70 hotel di Kota Bogor. Dari jumlah tersebut, sebanyak 23 hotel masuk dalam kategori bintang, sedangkan 40 hotel non bintang. Win's Hotel yang terletak di daerah Tegal Gundil, Cimahpar termasuk dalam kategori hotel melati (non bintang).

Dalam menghadapi perkembangan bisnis perhotelan di Kota Bogor yang semakin maju, Win's Hotel didirikan dengan tujuan agar bisnis tersebut dapat terkelola dengan baik dan hidup dalam jangka panjang. Untuk menunjang pencapaian tujuan tersebut, setiap perusahaan memiliki aset (asset) tertentu guna memperlancar kegiatan yang dilakukan oleh perusahaan.

Sebagian perusahaan menginvestasikan sebagian besar modalnya dalam bentuk aset yang bersifat tahan lama yang digunakan untuk operasi sehari-hari. Aset yang bersifat tahan lama ini disebut aset tetap. Aset tetap merupakan aset berwujud yang diperoleh dalam bentuk siap pakai atau dengan dibangun terlebih 
dahulu, yang digunakan dalam operasi perusahaan, tidak dimaksudkan untuk dijual dalam rangka kegiatan normal perusahaan, dan mempunyai masa manfaat lebih dari satu tahun. Aset tetap dan property investasi merupakan komponen dari aset tidak lancar. Aset tetap merupakan komponen aset yang paling besar nilainya di dalam neraca (Laporan Posisi Keuangan) sebagai besar perusahaan. (Dwi Martani, dkk (2012 : 270))

Aset tetap merupakan komponen yang sangat penting bagi perusahaan dalam menjalankan kegiatan operasionalnya. Aset tetap merupakan salah satu komponen dalam neraca, sehingga ketepatan dalam pengolahan aktiva tetap sangat berpengaruh terhadap kewajaran penilaiannya dalam laporan keuangan.

Kewajaran penilaian aset tetap suatu perusahaan dapat disesuaikan dengan Pernyataan Standar Akuntansi Keuangan (PSAK) No. 16 (2012) atau Standar Akuntansi Keuangan Entitas Tanpa Akuntabilitas Publik (SAK ETAP) Bab 15. Aset tetap dinyatakan sebesar harga perolehan dikurangi akumulasi penyusutan dan rugi penurunan nilai (jika ada).

Berdasarkan SAK ETAP Bab 15 paragraf 15.4 mengenai pengakuan aset tetap, entitas harus mengakui biaya perolehan aset tetap sebagai aset tetap jika :

(a) kemungkinan bahwa manfaat ekonomi yang terkait dengan pos tersebut akan mengalir dari atau ke dalam entitas; dan

(b) pos tersebut mempunyai nilai atau biaya yang dapat diukur dengan andal.

Aset tetap biasanya memiliki masa pemakaian lebih dari satu tahun, sehingga diharapkan dapat memberikan manfaat bagi perusahaan dalam jangka waktu relatif lama. Namun, manfaat yang diberikan aset tetap umumnya semakin lama semakin menurun manfaatnya secara terus menerus dan menyebabkan terjadinya penyusutan (depreciation).

Seiring dengan berlalunya waktu, aset tetap akan mengalami penyusutan (kecuali tanah). Faktor yang mempengaruhi penurunan kemampuan suatu aset 
tetap untuk memberikan jasa/manfaat yaitu secara fisik, disebabkan oleh pemakaian dan keausan karena penggunaan yang berlebihan dan secara fungsional, disebabkan oleh ketidakcukupan kapasitas yang tersedia dengan yang diminta (kemajuan teknologi). Sehingga penurunan kemampuan aset tetap tersebut dapat dialokasikan sebagai biaya.

Pengalokasian biaya penyusutan merupakan hal yang penting karena mempengaruhi laba yang dihasilkan oleh perusahaan. Apabila menggunakan metode penyusutan yang tidak sesuai dengan prinsip-prinsip yang berlaku atau kondisi perusahaan tersebut, maka akan mempengaruhi pendapatan yang dilaporkan setiap periode akuntansi dan mempengaruhi nilai dari aset tetap. Dalam menghitung penyusutan aset tetap terdapat beberapa metode yang dapat digunakan, antara lain : metode garis lurus (straight line method), metode unit produksi (units of production method), metode saldo menurun ganda (double declining balance method).

Win's Hotel merupakan salah satu perusahaan yang menyediakan jasa penginapan. Dalam menjalankan kegiatan operasionalnya, Win's Hotel ditunjang oleh aset tetap yang dimilikinya, seperti tanah, gedung, kendaraan, dan peralatan. Perhitungan pengakuan atas perolehan dan penyusutan masingmasing aset tetap ini tentunya berbeda-beda. Hal ini dapat mempengaruhi penyajian nilai aset tetap dan akumulasi penyusutan dalam laporan posisi keuangan perusahaan.

Berdasarkan uraian di atas, maka penulis tertarik untuk menyusun tugas akhir dengan judul "Tinjauan Atas Pengakuan dan Pengukuran Aset Tetap pada Win's Hotel." 


\subsection{Identifikasi Masalah}

Dalam membahas akuntansi aset tetap pada Win's Hotel, maka penyusun membagi menjadi 3 identifikasi masalah :

1. Bagaimana pengakuan atas aset tetap yang dimiliki Win's Hotel ?

2. Bagaimana pengukuran aset tetap Win's Hotel ?

3. Bagaimana penyajian aset tetap hotel dalam laporan posisi keuangan Win's Hotel ?

\subsection{Maksud dan Tujuan}

Adapun maksud dari penyusunan tugas akhir ini untuk memenuhi salah satu syarat kelulusan Diploma 3 Akuntansi.

Sedangkan tujuan penyusunan tugas akhir ini, diantaranya :

1. Untuk mengetahui bagaimana pengakuan aset tetap yang dimiliki oleh Win's Hotel.

2. Untuk mengetahui metode penyusutan yang digunakan Win's Hotel dalam membebankan penyusutan aset tetap yang dimilikinya.

3. Untuk mengetahui bagaimana penyajian aset tetap serta penyusutannya dalam laporan posisi keuangan Win's Hotel.

\subsection{Waktu dan Tempat Praktek Kerja}

Praktek kerja ini dilakukan penulis di Win's Hotel yang beralamat di Jl. H. Achmad Adnawijaya No. 11-D, Tegal Gundil, Bogor Utara. Praktek kerja ini dilaksanakan pada tanggal 26 April sampai dengan 26 Juli 2014 atau kurang lebih selama 3 bulan. Penulis melakukan kegiatan magang dari pukul 08.00 sampai dengan pukul 16.00 dari hari Senin sampai dengan Sabtu. 


\section{BAB II \\ TINJAUAN PUSTAKA}

\subsection{Aset Tetap}

\subsubsection{Pengertian Aset Tetap}

Menurut Pernyataan Standar Akuntansi Keuangan (2012 : 16.1) paragraf 6, menyatakan bahwa :

"Aset tetap adalah aset berwujud yang :

(a) dimiliki untuk digunakan dalam produksi atau penyediaan barang atau jasa, direntalkan kepada pihak lain, atau untuk tujuan administratif; dan

(b) diperkirakan untuk digunakan selama lebih dari satu periode."

Menurut Al. Haryono Jusup (2011 : 154) dalam bukunya yang berjudul

Dasar-dasar akuntansi, menyatakan bahwa :

Aset tetap adalah aktiva berujud yang digunakan dalam operasi perusahaan dan tidak dimaksudkan untuk dijual dalam rangka kegiatan normal perusahaan.

Menurut Kieso et al. (2011 : 388) dalam bukunya yang berjudul Financial Accounting, menyatakan bahwa :

Plant assets are resources that have three characteristics : They have a physical substance (a definite and shape), are used in the operations of a business, and are not intended for sale to customers.

Menurut Warren et al. (2008 : 440) dalam bukunya yang berjudul

Pengantar Akuntansi, menyatakan bahwa :

Aset tetap (fixed assets) merupakan aset jangka panjang atau aset aset yang relatif permanen. Mereka merupakan aset berwujud (tangible assets) karena terlihat secara fisik. Aset tersebut dimiliki dan digunakan oleh perusahaan serta tidak dimaksudkan untuk diual sebagai bagian dari operasi normal.

Menurut James M. Reeve et al. (2010 : 2) dalam bukunya yang berjudul Pengantar Akuntansi Adaptasi Indonesia, menyatakan bahwa : 
Aset tetap (fixed asset) adalah aset yang bersifat jangka panjang atau secara relative memiliki sifat permanen serta dapat digunakan dalam jangka panjang.

Menurut Soemarso S. R. (2005: 20) dalam bukunya yang berjudul Akuntansi Sebuah Pengantar Keuangan, menyatakan bahwa :

"Aset berwujud yang masa manfaatnya lebih dari satu tahun, digunakan dalam kegiatan perusahaan, dimiliki tidak untuk dijual kembali dalam kegiatan normal perusahaan, serta nilainya cukup besar."

\subsubsection{Klasifikasi Aset Tetap}

Menurut Efraim (2012 : 218) dalam bukunya yang berjudul Akuntansi Keuangan Menengah 1 Perspektif IFRS, membagi aset tetap menurut jenisnya yakni sebagai berikut :
a. Tanah
b. Bangunan
c. Mesin dan Peralatan
d. Mebel (lemari dan kursi)
e. Kendaraan
f. Lain-lain

Menurut Skousen et al. (2009 : 429) dalam bukunya yang berjudul Akuntansi Intermediate, klasifikasi dari aset tetap adalah :

\section{Aset Tetap Berwujud}

Aset tetap berwujud memiliki bentuk fisik dan dengan demikian dapat diamati dengan satu alat atau lebih panca indera dan memiliki karakteristik umum, yaitu memberi manfaat ekonomi pada masa mendatang bagi perusahaan. Aset tertentu yang umum dilaporkan di dalam kategori ini meliputi : 
a. Tanah

Merupakan harta yang digunakan untuk tujuan usaha dan tidak dikenai penyusutan, maka biaya yang dikenakan pada tanah merupakan biaya yang secara langsung berhubungan dengan masa manfaat yang tidak terbatas.

b. Perbaikan Tanah

Merupakan peningkatan kegunaan dari tanah tersebut. Unsur-unsur dari perbaikan tanah, seperti : pemetaan tanah, pengaspalan, pemagaraan, saluran air, instalasi listrik dan lain-lain.

c. Bangunan

Yang digunakan untuk menempatkan operasi perusahaan. Baik bangunan untuk kantor, toko, pabrik, maupun gudang yang digunakan dalam kegiatan utama perusahaan. Akan tetapi bangunan yang tidak digunakan dalam kegiatan perusahaan yaitu bangunan yang belum jadi (dalam tahap pembangunan) tidak dapat diklasifikasikan sebagai aset tetap.

d. Mesin dan Peralatan

Merupakan aset yang dipergunakan perusahaan dalam proses produksi atau penyediaan jasa.

e. Kendaraan

Merupakan aset yang dipergunakan sebagai alat transportasi atau sebagai penyedia jasa dan lain-lain seperti truk, mobil, motor.

\section{Aset Tak Berwujud}

Aset tak berwujud didefinisikan sebagai aset yang tidak memiliki bentuk fisik. Bukti adanya aset ini terdapat dalam bentuk perjanjian, kontrak atau paten. Hal ini memenuhi definisi aset karena adanya manfaat mendatang. Aset berikut umumnya dilaporkan aset tak berwujud : 
a. Paten

Suatu hak eksklusif yang memungkinkan seorang penemu/pencipta untuk mengendalikan produksi, penjualan atau penggunaan dari suatu temuan/ciptaannya.

b. Merk Dagang

Suatu hak eksklusif yang mengizinkan suatu simbol, label dan rancangan khusus.

c. Hak Cipta

Suatu hak eksklusif yang mengizinkan seorang untuk menjual, memberi izin atau mengendalikan pekerjaannya.

d. Goodwill

Sumber daya, faktor dan kondisi tak berwujud lain yang memungkinkan perusahaan untuk mendapatkan laba di atas laba normal dengan aset yang dapat diidentifikasi.

Menurut Al. Haryono Jusup (2011 : 155) dalam bukunya yang berjudul Dasar-dasar akuntansi, menyatakan bahwa :

Aktiva tetap biasanya digolongkan menjadi empat kelompok :

1. Tanah, seperti tanah yang digunakan sebagai tempat berdirinya gedunggedung perusahaan.

2. Perbaikan tanah, seperti jalan-jalan di seputar lokasi perusahaan, tempat parkir, pagar dan saluran air bawah tanah.

3. Gedung, seperti gedung yang digunakan untuk kantor, toko, pabrik dan gudang

4. Peralatan, seperti peralatan kantor, peralatan pabrik, mesin-mesin, kendaraan, dan meubel. 


\subsubsection{Karakteristik Aset Tetap}

Menurut Ng Eng Juan dan Ersa Tri Wahyuni (2012 : 340) dalam bukunya yang berjudul Panduan Praktis Standar Akuntansi Keuangan, menyatakan bahwa :

Agar dapat diklasifikasikan sebagai aset tetap menurut PSAK 16, suatu aset harus memiliki karakteristik-karakteristik berikut :

a. Aset tersebut digunakan dalam operasi. Hanya aset yang digunakan dalam operasi normal perusahaan saja yang dapat diklasifikasikan sebagai aset tetap.

b. Aset tersebut memiliki masa (umur) manfaat yang panjang. Lebih dari satu periode.

c. Aset tersebut memiliki substansi fisik. Aset tetap memiliki ciri substansi fisik kasat mata sehingga dibedakan dari aset tak berwujud seperti hak paten dan merek dagang.

\subsubsection{Pengukuran dan Pencatatan Aset Tetap}

Berdasarkan Pernyataan Standar Akuntansi Keuangan (2012 : 16.2) paragraf 07 , tercantum sebagai berikut :

"Biaya perolehan aset tetap harus diakui sebagai aset jika dan hanya jika :

(a) kemungkinan besar entitas akan memperoleh manfaat ekonomi masa depan dari aset tersebut; dan

(b) biaya perolehan aset dapat diukur secara andal."

Berdasarkan Standar Akuntansi Keuangan Entitas Tanpa Akuntabilitas Publik (2011 : 15.7), tertera sebagai berikut :

"Biaya perolehan aset tetap meliputi :

(a) harga beli, termasuk biaya hukum dan broker, bea impor dan pajak pembelian yang tidak boleh dikreditkan, setelah dikurangi diskon pembelian dan potongan lainnya;

(b) biaya-biaya yang dapat diatribusikan langsung untuk membawa aset ke lokasi dan kondisi yang diinginkan agar aset siap digunakan sesuai dengan maksud manajemen. Biaya-biaya ini termasuk biaya 
penyiapan lahan untuk pabrik, biaya penanganan dan penyerahan awal, biaya instalasi dan perakitan, dan biaya pengujian fungsionalitas;

(c) estimasi awal biaya pembongkaran aset, biaya pemindahan aset dan biaya restorasi lokasi. Kewajiban atas biaya tersebut timbul ketika aset tersebut diperoleh atau karena entitas menggunakan aset tersebut selama peride tertentu bukan untuk menghasilkan persediaan."

Menurut Al. Haryono Yusup (2011 : 160), aset tetap yang ada di perusahaan dapat diperoleh dengan berbagai cara, antara lain sebagai berikut :

1. Pembelian tunai

2. Pembelian angsuran

3. Perolehan aset tetap dengan konstruksi sendiri

4. Pertukaran dengan aset lain

a. Pertukaran aset sejenis

b. Pertukaran aset tidak sejenis

5. Perolehan aset tetap dengan cara sewa guna usaha (Leasing)

a. Sewa guna usaha modal (Capital Lease)

b. Sewa guna usaha operasi (Operating Lease)

Menurut Raja Adri Satriawan (2012 : 152-168) dalam bukunya yang berjudul Akuntansi Keuangan menjelaskan mengenai cara untuk mendapatkan aset tetap adalah sebagai berikut :

\section{Pembelian Tunai}

Aset tetap yang dibeli dengan tunai dicatat sebesar uang yang dikeluarkan untuk pembelian tersebut, ditambah dengan biaya-biaya lain sehubungan dengan pembelian tersebut. 
Bila ada potongan harga atau diskon maka harus dikurangi dari nilai perolehan. Tetapi jika diskon tersebut tidak diambil maka perusahaan harus melaporkannya sebagai discount lost.

Jurnal pembayaran tunai :

\begin{tabular}{|c|c|c|}
\hline Akun & Debit & Kredit \\
\hline \hline Aset Tetap & xxx & \\
\hline Kas & & $x x x$ \\
\hline
\end{tabular}

Jurnal pembayaran tunai jika diskon tidak diambil :

\begin{tabular}{|c|c|c|}
\hline Akun & Debit & Kredit \\
\hline \hline Aset Tetap & $\mathrm{xxx}$ & \\
\hline Discount Lost & $\mathrm{xxx}$ & \\
\hline Kas & & $\mathrm{xxx}$ \\
\hline
\end{tabular}

\section{Pembelian Angsuran}

Ada kalanya suatu aset tetap dibeli secara angsuran. Dalam hal demikian, kontrak pembelian dapat menyebutkan bahwa pembayaran akan dilakukan dalam sekian kali angsuran dan terhadap saldo yang belum bayar dikenakan bunga. Pembelian secara kredit merupakan salah satu cara untuk memperoleh suatu aset. Akan tetapi dengan cara ini timbulah pembayaran yang akan diangsur guna melunasi hutang akibat pembelian kredit ini. Jadi pencatatan yang harus dilaksanakan pada saat perolehan adalah :

\begin{tabular}{|c|c|c|}
\hline Akun & Debit & Kredit \\
\hline \hline Aset Tetap & $\mathrm{xxx}$ & \\
\hline Hutang Usaha & & $\mathrm{xxx}$ \\
\hline Kas & & $\mathrm{xxx}$ \\
\hline
\end{tabular}

Pencatatan pada saat pembayaran angsuran adalah : 


\begin{tabular}{|c|c|c|}
\hline Akun & Debit & Kredit \\
\hline \hline Hutang Usaha & $\mathrm{xxx}$ & \\
\hline Biaya Bunga & $\mathrm{xxx}$ & \\
\hline Kas & & $\mathrm{xxx}$ \\
\hline
\end{tabular}

\section{Penerbitan Surat-surat Berharga}

Aset tetap yang diperoleh melalui penerbitan surat berharga misalnya penerbitan saham ataupun obligasi), maka harga dari aset tetap tidak bisa diukur secara tepat. Jadi dasar pencatatan yang mungkin digunakan adalah nilai pasar surat berharga yang diterbitkan. Jika nilai pasar dari surat berharga yang ditukarkan tidak dapat ditentukan, maka nilai pasar aset tetap itu harus ditentukan oleh appraisal yang independen, dan dari hasil penilaian tersebut digunakan sebagai dasar mencatat aset dan penerbitan surat berharga. Jurnal yang dibuat jika laba :

\begin{tabular}{|c|c|c|}
\hline Akun & Debit & Kredit \\
\hline \hline Aset Tetap & $\mathrm{xxx}$ & \\
\hline Modal Saham/Obligasi & & $\mathrm{xxx}$ \\
\hline Agio Saham & & $\mathrm{xxx}$ \\
\hline
\end{tabular}

Jurnal yang dibuat jika rugi :

\begin{tabular}{|c|c|c|}
\hline \multicolumn{1}{|c|}{ Akun } & Debit & Kredit \\
\hline \hline Aset Tetap & $\mathrm{xxx}$ & \\
\hline Disagio & $\mathrm{xxx}$ & \\
\hline Modal Saham/Obligasi & & $\mathrm{xxx}$ \\
\hline
\end{tabular}

\section{Pertukaran Aset Lain}

Untuk aset tetap yang diperoleh melalui pertukaran berdasarkan Pernyataan Standar Akuntansi Keuangan (2012 : 16.5) paragraf 24, menyatakan bahwa : 
"Biaya perolehan dari suatu aset tetap diukur pada nilai wajar kecuali

(a) transaksi pertukaran tidak memiliki substansi komersial; atau

(b) nilai wajar aset yang diterima yang diserahkan tidak dapat diukur secara andal."

Jenis pertukaran aset dapat dilakukan ke dalam dua macam kasus yaitu :

a. Pertukaran Aset Sejenis

Syarat-syarat yang harus dipenuhi dalam pertukaran aset sejenis ini adalah sebagai berikut :

- Nilai pasar aset tetap yang dipertukarkan tidak diketahui.

- Aset tetap yang ditukarkan adalah sejenis

Pencatatan untuk transaksi pertukaran aset tetap sejenis ini adalah keuntungan dikurangkan pada harga aset tetap, sedangkan kerugian dibebankan dalam tahun berjalan. Contohnya pertukaran peralatan lama dengan peralatan baru. Jurnal yang dibuat jika laba atau gain adalah :

\begin{tabular}{|c|c|c|}
\hline Akun & Debit & Kredit \\
\hline \hline Beban Penyusutan & $\mathrm{xxx}$ & \\
\hline Akumulasi Penyusutan & & $\mathrm{xxx}$ \\
\hline & & \\
\hline Peralatan (baru) & $\mathrm{xxx}$ & \\
\hline Akumulasi Penyusutan & $\mathrm{xxx}$ & \\
\hline Peralatan (lama) & & $\mathrm{xxx}$ \\
\hline Kas & & $\mathrm{xxx}$ \\
\hline Keuntungan dari pertukaran & & $\mathrm{xxx}$ \\
\hline
\end{tabular}

Jurnal yang dibuat jika rugi atau loss adalah :

\begin{tabular}{|c|c|c|}
\hline \multicolumn{1}{|c|}{ Akun } & Debit & Kredit \\
\hline \hline Beban Penyusutan & xxx & \\
\hline Akumulasi Penyusutan & & xxx \\
\hline & & \\
\hline Peralatan (baru) & xxx & \\
\hline Akumulasi Penyusutan & xxx & \\
\hline Kerugian Penyusutan & xxx & \\
\hline Peralatan (lama) & & xxx \\
\hline Kas & & xxx \\
\hline
\end{tabular}


b. Pertukaran Aset Tidak Sejenis

Syarat-syarat yang harus dipenuhi dalam pertukaran aset tidak sejenis adalah sebagai berikut :

- Aset yang dipertukarkan tidak sejenis, tetapi tidak termasuk dalam Producting Assets

- Cost kedua aset tersebut diketahui nilai pasarnya

Pencatatan untuk transaksi pertukaran aset tidak sejenis ini adalah keuntungan atau kerugian dibebankan dalam tahun berjalan. Contohnya pertukaran tanah dengan mesin.

Jurnal yang akan dibuat jika laba atau gain adalah :

\begin{tabular}{|l|c|c|}
\hline \multicolumn{1}{|c|}{ Akun } & Debit & Kredit \\
\hline \hline Beban Penyusutan & $\mathrm{xxx}$ & \\
\hline Akumulasi Penyusutan & & $\mathrm{xxx}$ \\
\hline & & \\
\hline Tanah & $\mathrm{xxx}$ & \\
\hline Akumulasi Penyusutan & $\mathrm{xxx}$ & \\
\hline Mesin & & $\mathrm{xxx}$ \\
\hline Kas & & $\mathrm{xxx}$ \\
\hline Keuntungan dari pertukaran & & $\mathrm{xxx}$ \\
\hline
\end{tabular}

Jurnal yang akan dibuat jika rugi atau loss adalah :

\begin{tabular}{|l|c|c|}
\hline \multicolumn{1}{|c|}{ Akun } & Debit & Kredit \\
\hline \hline Beban Penyusutan & xxx & \\
\hline Akumulasi Penyusutan & & xxx \\
\hline & & \\
\hline Tanah & xxx & \\
\hline Akumulasi Penyusutan Aset Tetap & xxx & \\
\hline Kerugian dari pertukaran & xxx & \\
\hline Mesin & & xxx \\
\hline Kas & & xxx \\
\hline
\end{tabular}




\section{Perolehan Aset Tetap dengan Konstruksi Sendiri}

Kadang kala aset tetap dibuat atau dirakit sendiri oleh perusahaan untuk digunakan sendiri. Aset tetap dicatat pada harga perolehannya, termasuk semua pengeluaran yang terjadi untuk membuat aset dan mempersiapkan aset tersebut untuk digunakan dalam kegiatan operasional perusahaan. Semua biaya yang dapat dikaitkan dengan konstruksi dapat dibebankan ke aset tersebut antara lain : biaya bahan baku, biaya tenaga kerja, biaya konstruksi, biaya asuransi selama masa pembangunan, dan biaya kontraktor. Selain itu, biaya bunga atas pinjaman yang terjadi akibat pembiayaan pembangunan atau perakitan aset tersebut harus dimasukkan sebagai biaya perolehan aset.

Berdasarkan Pernyataan Standar Akuntansi Keuangan (2012 : 16.5) paragraf 22, mengemukakan :

"Biaya perolehan suatu aset yang dikonstruksi sendiri ditentukan dengan menggunakan prinsip yang sama sebagaimana aset yang diperoleh bukan dengan konstruksi sendiri. Jika entitas membuat aset serupa untuk dijual dalam kegiatan usaha normal, biaya perolehan aset biasanya sama dengan biaya konstruksi aset untuk dijual (lihat PSAK 14:Persediaan). Oleh karena itu, dalam menetapkan biaya perolehan maka setiap laba internal dieliminasi. Demikian pula biaya pemborosan yang terjadi dalam pemakaian bahan baku, tenaga kerja, atau sumber daya lain dalam aset yang dikonstruksi sendiri tidak termasuk biaya perolehan aset tersebut. PSAK 26: Biaya Pinjaman menetapkan kriteria pengakuan bunga sebagai komponen biaya perolehan aset tetap yang dikonstruksi sendiri."

Adapun alasan yang menjadi pendorong perusahaan untuk membangun atau membuat sendiri aset tetap yang diperlukan dalam kegiatan operasinya antara lain : untuk menekan biaya konstruksi dengan memanfaatkan fasilitas yang menganggur dan keinginan untuk mendapatkan mutu yang lebih baik. 


\section{Perolehan Aset Tetap dari Sumbangan}

Ketika aset diperoleh melalui sumbangan (donation), tidak ada biaya yang dapat digunakan sebagai dasar perhitungannya. Meskipun ada pengeluaran guna memperoleh aset, biasanya jauh lebih kecil dibandingkan dengan nilai aset tersebut. Saat sumber daya yang berharga ditemukan pada lahan yang telah dimiliki, penemuan (discovery) ini akan meningkatkan nilai aset.Tetapi, karena harga perolehan tanah tidak dipengaruhi oleh penemuan tersebut maka kenaikan tersebut biasanya diabaikan.

Berdasarkan Pernyataan Standar Akuntansi Keuangan (2012 : 61) paragraf 02, adalah :

"Hibah yang terkait dengan aset adalah hibah pemerintah yang kondisi utamanya adalah bahwa entitas yang memenuhi syarat harus melakukan pembelian, membangun atau membeli aset jangka panjang. Kondisi tambahan mungkin juga ditetapkan dengan membatasi jenis atau lokasi aset atau periode aset tersebut diperoleh atau dimiliki."

Jurnal yang dibuat untuk mencatat transaksi ini adalah :

\begin{tabular}{|c|c|c|}
\hline Akun & Debit & Kredit \\
\hline \hline Aset Tetap & xxx & \\
\hline Modal Donasi & & xxx \\
\hline
\end{tabular}

\section{Perolehan Aset Tetap dengan cara Sewa Guna Usaha (Leasing)}

Berdasarkan Pernyataan Standar Akuntansi Keuangan (2012 : 30.1) paragraf 04, adalah :

"Sewa adalah suatu perjanjian dimana lessor memberikan kepada lessee hak untu menggunakan suatu aset selama periode waktu yang disepakati. Sebagai imbalannya, lessee melakukan pembayaran atau serangkaian pembayaran kepada lessor." 
Menurut Warren et al. (2008 : 511), pencatatan cara perolehan ini tergantung dari jenis leasing yang diambil oleh perusahaan. Ada dua cara sewa guna usaha, yaitu :

\section{a. Sewa Guna Usaha Modal (Capital Lease)}

Suatu sewa guna usaha diklasifikasi sebagai sewa guna usaha modal (capital lease) jika lease pada dasarnya dianggap telah membeli aset. Aset yang diperoleh dengan cara ini dicatat sebagai aset tetap dalam kelompok tersendiri dan juga harus diamortisasikan. Kewajiban sewa guna usahanya pun disajikan terpisah dari kewajiban lainnya. Biasanya cara ini diambil bila aset tetap disewa lebih dari dua tahun.

b. Sewa Guna Usaha Operasi (Operating Lease)

Lessee mencatat pembayaran menurut sewa guna usaha operasi dengan mendebit beban sewa dan mengkredit kas. Bila perusahaan memilih cara ini maka pencatatan angsuran tiap bulan tidak dianggap sebagai aset tetap tetapi langsung merupakan biaya sewa aset yang diakui dan dicatat berdasarkan metode garis lurus selama masa sewa guna usaha, meskipun pembayaran dilakukan dalam jumlah yang tidak sama setiap periode.

Menurut Ng Eng Juan dan Ersa Tri Wahyuni dalam bukunya yang berjudul Panduan Praktis Standar Akuntansi Keuangan, menyatakan bahwa :

PSAK 16 menyatakan bahwa biaya perolehan awal aset tetap meliputi (paragraf 16) :

a. Harga perolehannya

b. Biaya-biaya yang dapat diatribusikan secara langsung untuk membawa aset tersebut ke lokasi dan kondisi yang diinginkan agar aset siap digunakan sesuai dengan keinginan dan maksud manajemen.

c. Estimasi awal biaya pembongkaran dan pemindahan aset tetap serta restorasi lokasi aset, liabilitas atas biaya tersebut timbul ketika aset diperoleh. 
Menurut Al. Haryono Yusup (2011 : 156) dalam bukunya yang berjudul Dasar-dasar Akuntansi, menguraikan penerapan prinsip harga perolehan untuk tiap golongan utama aktiva tetap sebagai berikut :

a. Tanah

Harga perolehan tanah meliputi : harga beli tunai tanah, biaya balik nama, komisi perantara, pajak atau pungutan lain yang harus dibayar oleh pembeli.

b. Perbaikan Tanah

Harga perolehan perbaikan tanah meliputi semua pengeluaran yang dilakukan sampai perbaikan siap untuk digunakan sebagaimana dimaksud dengan perbaikan tersebut.

c. Gedung

Semua pengeluaran yang berhubungan dengan pembelian atau pembangunan sebuah gedung harus dibebankan pada rekening Gedung. Apabila gedung dimiliki melalui pembelian, maka harga perolehannya meliputi harga beli, biaya notaris dan komisi perantara. Namun seandainya gedung dibangun sendiri, maka harga perolehannya meliputi semua pengeluaran untuk membuat gedung, termasuk saluran listrik dan air.

d. Peralatan

Harga perolehan peralatan terdiri dari harga beli tunai, biaya pengangkutan dan biaya asuransi selama dalam pengangkutan yang dibayar oleh pembeli. Termasuk pula di dalamnya pengeluaran untuk perakitan, pemasangan dan pengujian peralatan yang dibeli. Bea balik nama kendaraan juga harus ditambahkan pada harga perolehan kendaraan.

Menurut James M. Reeve et al. (2010: 4) dalam bukunya yang berjudul Pengantar Akuntansi Adaptasi Indonesia, menjelaskan bahwa : 
Biaya perolehan aset tetap mencakup seluruh jumlah yang dikeluarkan untuk mendapatkan aset hingga siap untuk digunakan. Sebagai contoh, biaya pengiriman dan biaya pemasangan peralatan dimasukkan sebagai bagian dari jumlah biaya aset. Hanya biaya yang diperlukan untuk menyiapkan aset jangka panjang hingga dapat digunakan yang perlu dimasukkan sebagai aset. Biayabiaya yang tidak perlu dan tidak meningkatkan kegunaan aset dicatat sebagai beban.

Menurut Soemarso S. R (2005 : 20) dalam bukunya yang berjudul Akuntansi Suatu Pengantar, menyatakan bahwa :

Semua biaya yang terjadi untuk perolehan suatu aset tetap sampai tiba di tempat dan siap digunakan harus dimasukkan sebagai bagian dari harga perolehan (cost) aset yang bersangkutan. Dengan demikian harga perolehan suatu aset tetap tidak terbatas pada harga belinya saja. Termasuk harga perolehan adalah biaya pengiriman, asuransi, pemasangan, dan bea balik nama.

Menurut Skousen et al. (2009 : 5) dalam bukunya yang berjudul Akuntansi Intermediate, menguraikan bahwa :

Harga perolehan aset tetap semua jumlah dana yang dikeluarkan untuk mendapatkan aset tetap dan membuatnya siap digunakan adalah :

1. Tanah

Karena tanah adalah aset yang tidak disusutkan, maka biaya yang dikenakan pada tanah haruslah biaya yang secara langsung berhubungan dengan masa manfaat tanah yang tidak terbatas.

Biaya yang terkait dalam perolehan tanah, antara lain : harga pembelian, biaya pajak, biaya pembersihan, biaya peningkatan mutu tanah, biaya untuk memindahkan atau menghancurkan gedung yang tidak dibutuhkan, biaya perizinan dari badan-badan pemerintah, bea balik nama, biaya pengaspalan jalan. 
2. Bangunan

Harga perolehan bangunan termasuk biaya yang diperlukan untuk memperbaiki kondisi bangunan sebelum ditempati, biaya jasa arsitek, biaya jasa insinyur, biaya asuransi selama konstruksi, bunga atas pinjaman untuk membiayai, jalan setapak dan sekitar bangunan, perbaikan (pembelian bangunan bekas), restorasi (pembelian bangunan bekas), modifikasi untuk penggunaan, izin dari badanbadan pemerintah.

3. Mesin dan Peralatan

Harga perolehan peralatan meliputi biaya angkut dan asuransi selama mesin dan peralatan tersebut dalam perjalanan, dan biaya yang keluar untuk uji coba dan pemasangan, harga beli, pajak, perbaikan (pembelian peralatan dan mesin bekas), restorasi (pembelian peralatan dan mesin bekas), asuransi pengangkutan, biaya perakitan, modifikasi untuk penggunaan, izin dari badanbadan pemerintah.

\section{Perbaikan Tanah}

Harga perolehan perbaikan tanah meliputi biaya-biaya sebagai berikut : biaya pemetaan tanah, pengaspalan dan pemagaran, biaya perbaikan, pepohonan dan rerumputan, penerangan halaman, pegaspalan area parkir.

Pencatatan akuntansi terhadap pengeluaran yang berhubungan dengan perolehan dan penggunaan aset tetap dapat dibagi menjadi dua, yaitu :

\section{Pengeluaran Pendapatan (Revenue Expenditures)}

Menurut Soemarso S. R (2005 : 52), menjelaskan bahwa :

"Pengeluaran pendapatan adalah pengeluaran-pengeluaran yang hanya mendatangkan manfaat untuk tahun dimana pengeluaran tersebut dilakukan. Oleh karena itu, pengeluaran pendapatan akan dicatat sebagai beban."

Pengeluaran pendapatan itu meliputi : 
a. Reparasi (Repairs)

Pengeluaran untuk memperbaiki Fixed Asset yang mengalami kerusakan sebagian atau seluruhnya, agar dapat dipergunakan dan menjalankan fungsinya lagi sebagaimana mestinya. Apabila sifat repair ini hanya mengembalikan Fixed Asset yang rusak menjadi seperti keadaan semula, tanpa mengadakan penggantian terhadap bagian-bagian tertentu dari Fixed Asset tersebut yang nilainya cukup besar, maka pengeluaran ini dibukukan sebagai biaya dan dicatat dalam perkiraan Repair Expense.

b. Pemeliharaan (Maintenance)

Pengeluaran untuk memelihara agar aset tetap yang bersangkutan tidak cepat usang atau rusak dari waktu ke waktu. Oleh karena itu, Maintenance tidak secara langsung menaikkan nilai Fixed Asset itu sendiri, maka pengeluaran ini dibukukan sebagai biaya dan dicatat dalam perkiraan Repair Expense.

c. Penggantian

Penggantian adalah biaya yang dikeluarkan untuk mengganti aset dengan unit baru yang tipenya sama, misalnya penggantian dinamo mesin. Penggantian seperti biasanya terjadi karena aset tetap lama sudah tidak berfungsi lagi (rusak). Penggantian bagian-bagian aset yang biayanya kecil diperlakukan dengan cara yang sama dengan reparasi kecil, yaitu diperlakukan sebagai beban. Apabila biayanya cukup besar, maka harga perolehan bagian itu dihapuskan dari rekening aset dan diganti dengan harga perolehan yang baru. Begitu juga akumulasi depresiasi untuk bagian yang diganti dihapuskan.

Menurut James M. Reeve et al. (2010 : 4) dalam bukunya yang berjudul Pengantar Akuntansi Adaptasi Indonesia, menyatakan bahwa :

Pengeluaran Pendapatan (Revenue Expenditure) atau perawatan dan perbaikan biasa adalah pengeluaran yang terkait dengan 
perawatan dan perbaikan aset tetap yang dicatat sebagai beban periode berjalan.

Sebagai contoh, sejumlah Rp 300.000 yang dibayarkan untuk perawatan truk pengiriman dicatat sebagai berikut :

\begin{tabular}{|c|l|l|}
\hline Akun & Debit & Kredit \\
\hline \hline Beban Perbaikan dan Perawatan & 300.000 & \\
\hline Kas & & 300.000 \\
\hline
\end{tabular}

\section{Pengeluaran Modal (Capital Expenditures)}

Menurut Soemarso S. R (2005 : 52) dalam bukunya yang berjudul Akuntansi Suatu Pengantar, menjelaskan bahwa :

"Pengeluaran modal adalah pengeluaran-pengeluaran yang harus dicatat sebagai aset (dikapitalisasi). Pengeluaran-pengeluaran yang akan mendatangkan manfaat lebih dari satu periode akuntansi termasuk dalam kategori ini."

Pengeluaran modal ini meliputi :

a. Reparasi besar dan mempunyai manfaat selama sisa umur penggunaan, tetapi tidak menambah umur penggunaannya. Pengeluaran ini adalah untuk memperbaiki aset tetap yang mengalami kerusakan sebagian atau seluruhnya, agar dapat menjalankan fungsinya kembali dengan mengadakan penggunaan dari bagian-bagian tertentu dari aset tersebut yang cukup besar.

b. Reparasi besar yang menambah umur manfaat aset tetap. Pengeluaran untuk reparasi ini adalah penggantian aset tetap yang disebabkan karena bagian yang diganti dalam keadaan rusak berat. Pengeluaran ini memberikan manfaat pada periode operasi di luar periode sekarang juga menambah umur penggunaan aset tetap yang bersangkutan. Pengeluaran ini tidak dibukukan sebagai biaya, tetapi dikapitalisasikan dengan mendebet perkiraan akumulasi penyusutan. 
c. Perbaikan (Betterment/Improvement)

Pengeluaran yang meningkatkan efisiensi atau kapitalisasi operasi aset tetap selama umur manfaatnya. Jika manfaatnya lebih dari satu periode akan dikapitalisir dalam cost aset.

d. Penambahan (Addition)

Suatu penambahan biasanya mengakibatkan bertambah besarnya fasilitas fisik. Penambahan dicatat dengan mendebet rekening aset yang mengalami penambahan aset pengeluaran tersebut, dan penyusutan selama umur ekonomis.

Menurut James M. Reeve et al. (2010 : 4) dalam bukunya yang berjudul Pengantar Akuntansi Adaptasi Indonesia, menyatakan bahwa :

Pengeluaran Modal (Capital Expenditure) adalah pengeluaran yang meningkatkan nilai aset atau memperpanjang masa kegunaan aset.

Terdapat 2 jenis pengeluaran modal, yaitu :

a. Peningkatan Nilai Aset

Setelah aset tetap disiapkan, pengeluaran dapat terjadi untuk meningkatkan nilai aset. Sebagai contoh, nilai jasa truk pengiriman dapat ditingkatkan dengan menambah alat pengangkat hidrolik senilai Rp 5.500.000 untuk mempermudah dan mempercepat bongkar muat barang berat. Dalam kasus pengangkat hidrolik, pengeluaran dicatat sebagai berikut :

\begin{tabular}{|c|c|c|}
\hline Akun & Debit & Kredit \\
\hline \hline Truk Pengiriman & 5.500 .000 & \\
\hline Kas & & 5.500 .000 \\
\hline
\end{tabular}

Oleh karena biaya truk pengiriman meningkat, penyusutan truk tersebut berubah sesuai sisa masa kegunaannya.

b. Perbaikan Luar Biasa 
Setelah aset tetap disiapkan, pengeluaran dapat terjadi untuk memperpanjang masa kegunaan aset. Sebagai contoh, mesin forklift yang sudah mendekati akhir masa kegunaannya hingga 8 tahun. Pengeluaran semacam ini dicatat sebagai penurunan pada akun akumulasi penyusutan. Dalam kasus forklift, pengeluaran akan dicatat sebagai berikut :

\begin{tabular}{|c|c|c|}
\hline Akun & Debit & Kredit \\
\hline \hline Akumulasi Penyusutan-Forklift & 4.500 .000 & \\
\hline Kas & & 4.500 .000 \\
\hline
\end{tabular}

Oleh karena sisa masa kegunaan forklift telah berubah, penyusutannya juga berubah mengikuti nilai buku forklift yang baru.

\subsection{Penyusutan Aset Tetap}

\subsubsection{Pengertian Penyusutan}

Menurut Kieso et al. (2011 : 392) dalam bukunya yang berjudul Financial Accounting menyatakan bahwa :

Depreciation isnthe process of allocating to expense the cost of a plant asset over its useful (service) life in a rational and systematic manner

Menurut Warren et al. (2008 : 443) dalam bukunya yang berjudul Pengantar Akuntansi menyatakan bahwa :

Jenis aset tetap (kecuali tanah) seperti peralatan, bangunan dan pengembangan tanah (land improvement) akan kehilangan kemampuan mereka seiring dengan berlalunya waktu, untuk menyediakan manfaat kepada perusahaan. Karenanya biaya peralatan, bangunan dan pengembangan tanah harus ditransfer ke akun beban dengan cara yang sistematis sepanjang umur manfaatnya. Transfer periodik ini, dari biaya ke beban dinamakan dengan penyusutan atau depresiasi (depreciation).

Menurut Pernyataan Standar Akuntansi Keuangan (2012 : 16.2) paragraf 6, yaitu :

Penyusutan adalah alokasi sistematis jumlah tersusutkan dari aset selama umur manfaatnya. 
Menurut Dwi Martani, dkk (2012 : 313) dalam bukunya yang berjudul Akuntansi Keuangan Menengah Berbasis PSAK, menjelaskan bahwa :

Penyusutan adalah metode pengalokasian biaya aset tetap untuk menyusutkan nilai aset secara sistematis selama periode manfaat dari aset tersebut.

Menurut Raja Adri Satriawan Surya (2012 : 173) dalam bukunya yang berjudul Akuntansi Keuangan Versi IFRS, menjelaskan bahwa :

Penyusutan adalah alokasi jumlah yang dapat disusutkan dari suatu aset sepanjang masa manfaat yang estimasi. Jumlah yang dapat disusutkan dari suatu aset adalah biaya yang dikeluarkan untuk memperoleh aset tersebut dikurangi dengan estimasi nilai sisa (salvage value) aset tersebut pada akhir "masa manfaatnya."

Menurut Al Haryono Jusup (2011 : 162) dalam bukunya yang berjudul Dasar-Dasar Akuntansi, menyatakan bahwa :

Depresiasi adalah roses pengalokasian harga perolehan aktiva tetap menjadi biaya selama masa manfaatnya dengan cara yang rasional dan sistimatis.

Dari pengertian di atas dapat disimpulkan bahwa penyusutan adalah suatu metode pengalokasian harga perolehan aset setelah dikurangi nilai sisa yang dialokasikan ke periode-periode yang menerima manfaat dari aset tetap tersebut. Jumlah penyusutan menunjukkan bahwa penyusutan bukan merupakan proses penilaian aset, melainkan proses pengalokasian harga perolehan aset.

\subsubsection{Faktor-faktor dalam menentukan biaya penyusutan}

Terdapat tiga faktor yang dipertimbangkan dalam menentukan jumlah beban penyusutan tahunan yang tepat menurut Skousen et al. (2009: 105), yaitu

\section{Harga Perolehan Aset Tetap (Cost)}

Menurut Pernyataan Standar Akuntansi Keuangan (2012 : 16.4) paragraf 16, menguraikan komponen biaya perolehan meliputi : 
(a) harga perolehannya, termasuk bea impor dan pajak pembelian yang tidak boleh dikreditkan setelah dikurangi diskon pembelian dan potongan lain.

(b) Setiap biaya yang dapat diatribusikan secara langsung untuk membawa aset ke lokasi dan kondisi yang diinginkan supaya aset tersebut siap digunakan sesuai dengan maksud manajemen.

(c) estimasi awal biaya pembongkaran dan pemindahan aset tetap dan restorasi lokasi aset tetap. Kewajiban tersebut timbul ketika aset tetap diperoleh atau sebagai konsekuensi penggunaan aset tetap selama periode tertentu untuk tujuan selain untuk menghasilkan persediaan.

Harga perolehan suatu aset tetap meliputi semua pengeluaran yang berhubungan dengan perolehan dan persiapan penggunaan aset tersebut. Harga perolehan dikurangi dengan nilai sisa, jika ada adalah harga perolehan yang dapat disusutkan atau dasar penyusutan, yaitu jumlah harga aset yang akan dibebankan pada periode-periode mendatang.

\section{Nilai Residu atau Nilai Sisa (Residual Value)}

Menurut Pernyataan Standar Akuntansi Keuangan (2012 :16.3) paragraf 6, bahwa :

"Nilai residu dari aset adalah estimasi jumlah yang dapat diperoleh entitas saat ini dari pelepasan aset, setelah dikurangi estimasi biaya pelepasan, jika aset telah mencapai umur dan kondisi yang diperkirakan pada akhir umur manfaatnya."

Nilai sisa (residu) suatu aset adalah perkiraan harga penjualan aset pada saat aset tersebut dijual setelah dihentikan pemakaiannya. Nilai sisa tergantung pada kebijaksanaan penghentian aset dalam perusahan serta keadaan pasar.

\section{Umur Ekonomis atan Masa Manfaat (Useful Life)}

Berdasarkan Pernyataan Standar Akuntansi Keuangan (2012 : 16.2) paragraf 6 , adalah :

"Umur manfaat adalah :

a) Periode aset diperkirakan dapat dihgunakan oleh entitas, atau

b) Jumlah produksi atau unit serupa dari aset yang diperkirakan akan diperoleh oleh entitas." 
Aset operasi tidak lancar selain tanah memiliki masa manfaat yang terbatas sebagai akibat dari faktor fisik dan fungsional. Faktor fisik yang membatasi masa manfaat suatu aset adalah : kerusakan, keausan, kehancuran. Kerusakan pada penggunaan aset tetap seperti mobil, gedung atau furniture yang menyebabkan aset tersebut tidak dapat digunakan kembali, dapat juga disebabkan oleh usia, kebakaran, banjir, gempa dan kecelakaan yang dapat menghentikan masa manfaat dari suatu aset.

Faktor fungsional utama yang membatasi masa manfaat aset adalah keusangan. Suatu aset dapat kehilangan kegunaannya sebagai akibat dari perubahan dalam kebutuhan dunia usaha atau kemajuan teknologi, sehingga tidak dapat lagi menghasilkan pendapatan yang mencukupi untuk dijadikan alasan dari penggunaan aset tersebut. Meskipun aset tersebut secara fisik masih dapat dipergunakan, ketidakmampuannya menghasilkan pendapatan yang memadai telah memperpendek masa manfaatnya.

\subsubsection{Metode Penyusutan Aset Tetap}

Berdasarkan Pernyataan Standar Akuntansi Keuangan (2012 : 16.18) paragraf 63 , dijelaskan bahwa berbagai metode penyusutan dapat digunakan untuk mengalokasikan jumlah tersusutkan dari aset secara sistematis selama umur manfaatnya.

Sedangkan menurut Raja Adri Satriawan Surya (2012 : 174), menjelaskan bahwa penyusutan dapat dilakukan dengan berbagai metode yang dapat dikelompokkan menurut kriteria berikut :

a. Berdasarkan waktu

(i) Metode garis lurus (straight line method)

(ii) Metode pembebanan menurun (decreasing charge methods)

- Metode saldo menurun (declining balance method) 
- Metode jumlah angka tahun (sum of the year digit method)

b. Berdasarkan penggunaan

(i) Metode jam jasa (service hours method)

(ii) Metode jumlah unit (productive output method)

Dari berbagai metode di atas, dapat dijelaskan lebih lanjut sebagai berikut :

\section{Metode Garis Lurus (Straight Line Method)}

Metode garis lurus mengalokasikan jumlah yang dapat disusutkan dari suatu aset dalam jumlah yang sama besar selama estimasi masa manfaatnya. Beban penyusutan setiap tahunnya dapat dihitung dengan mengalikan tarif penyusutan dengan dasar penyusutan. Dasar penyusutan yang digunakan adalah biaya perolehan aset dikurangi dengan nilai sisanya. Secara matematis beban penyusutan dapat dihitung sebagai berikut :

$$
\text { Penyusutan per tahun }=\frac{\text { Harga Perolehan }- \text { Nilai Residu }}{\text { Estimasi Manfaat }(\text { dalam tahun })}
$$

Jurnal untuk mencatat penyusutan tiap tahun adalah :

\begin{tabular}{|c|c|c|}
\hline Akun & Debit & Kredit \\
\hline \hline Beban Penyusutan & xxx & \\
\hline Akumulasi Depresiasi & & xxx \\
\hline
\end{tabular}

\section{Metode Pembebanan Menurun (Decreasing Charge Methods)}

Metode pembebanan menurun yang dikenal juga dengan sebutan metode penyusutan dipercepat (accelerated depreciation methods) membebankan penyusutan yang lebih tinggi pada tahun-tahun awal dan beban yang lebih rendah pada tahun-tahun akhir.

\section{a. Metode Saldo Menurun (Declining Balanced Method)}


Metode saldo menurun menghasilkan beban penyusutan periodik yang semakin menurun sepanjang umur estimasi aktiva itu. Teknik yang paling umum adalah dengan melipatgandakan tarif penyusutan (diekspresikan sebagai persentase) garis lurus, yang dihitung tanpa memperhatikan nilai residu, dan menggunakan tarif penyusutan yang dihasilkan terhadap harga perolehan aset dikurangi akumulasi penyusutan. Tarif saldo menurun tetap konstan dan diaplikasikan pada nilai buku yang menghasilkan nilai penyusutan yang terus menurun setiap tahunnya. Proses ini terus berlangsung hingga nilai buku aktiva berkurang mencapai estimasi nilai sisanya, dimana pada saat tersebut penyusutan akan dihentikan. Tarif saldo menurun berganda untuk aktiva 5 tahun akan menjadi $40 \%$ (dua kali tarif garis lurus, $20 \% \times 2=40 \%$ ).

Beban Penyusutan $=$ Tarif Penyusutan $\times($ Harga Perolehan - Nilai Sisa $)$

\section{Beban Penyusutan $=$ Tarif Penyusutan $\times$ Dasar Penyusutan \\ Dasar Penyusutan $=$ Nilai Buku Awal Periode}

Tarif penyusutan yang digunakan adalah dua kali tarif metode garis lurus.

\section{b. Metode Jumlah Angka Tahun (Sum of The Years Digits Method)}

Metode ini merupakan metode depresiasi yang dihasilkan dari penghapusbukuan yang bersifat menurun dimana biaya depresiasi tahunan ditentukan dengan mengalikan biaya depresiasi dengan fraksi tahun sebagai tarif pembebanan depresiasi. Tarif pembebanan depresiasi merupakan rasio dengan denominatornya adalah jumlah tahun pengguna aset (misalnya aset dengan masa manfaat 5 tahun memiliki denominator $15(5+4+3+2+1)$ dan numeratornya adalah jumlah tahun sisa pada awal tahun yang belum didepresiasikan. 
Dengan metode ini, fraksi pengali pada metode ini numerator tersebut akan menurun seiring waktu dan denominator tersebut akan menurun seiring waktu dan denominatornya tetap $(5 / 15,4 / 15,3 / 15,2 / 15$ dan 1/15). Pada akhir masa manfaat aktiva, saldo yang tersisa harus sama dengan nilai sisa.

Beban Penyusutan $=$ Tarif Penyusutan $x($ Harga Perolehan - Nilai Sisa $)$

\section{Metode Jam Jasa (Service Hours Method)}

Metode jam jasa membebankan penyusutan untuk suatu periode berdasarkan jumlah jam yang digunakan oleh suatu aset dalam memberikan jasa dalam rangka operasi perusahaan selama periode tersebut. Tarif penyusutan per jam diperoleh dengan cara membagi jumlah yang dapat disusutkan dari sutu aset dengan estimasi masa manfaat aset tersebut dalam jam. Secara matematis, tarif penyusutan per jam dapat dihiutng sebagai berikut :

$$
\text { Tarif Penyusutan } \quad=\quad \frac{\text { Biaya Perolehan }- \text { Nilai Sisa }}{\text { Estimasi Masa Manfaat (dalam jam) }}
$$

\section{Metode Jumlah Unit Produksi (Productive Output Method)}

Metode jumlah unit produksi membebankan penyusutan untuk suatu periode berdasarkan jumlah unit yang diproduksi oleh suatu aset dalam operasi perusahaan selama periode tersebut. Tarif penyusutan per unit diperoleh dengan cara membagi jumlah yang dapat disusutkan dari suatu aset dengan estimasi total unit yang dapat diproduksi oleh suatu aset selama masa manfaatnya. Secara sistematis, tarif penyusutan per unit dapat dihitung dengan rumus sebagai berikut : 


\section{BAB III}

\section{HASIL DAN PEMBAHASAN}

\subsection{Sejarah Perusahaan}

Win's Hotel didirikan sejak awal tahun 2011 dengan konsep 'Low Budget Family Hotel'. Hotel yang bersih, nyaman serta elegan dengan harga terjangkau, dan pelayanan yang memberikan kenyamanan bagi setiap pelanggan. Win's Hotel juga bekerja sama dengan Agoda.com dan Klikhotel.com sehingga dapat melayani pelanggan tidak hanya dari dalam negeri namun juga mancanegara. Dalam pengembangan Win's Hotel, manajemen terus menerus melakukan perbaikan untuk meningkatkan pelayanan kepada pelanggan.

\section{Visi :}

Mengembangkan Win's Hotel menjadi 'Family Hotel' yang ada di berbagai wilayah Indonesia, dan menjadi pilihan utama bagi pengunjung yang ingin mendapatkan pelayanan terbaik dengan harga terjangkau.

Misi :

Ramah dalam melayani, mengutamakan kebersihan dan kenyamanan bagi pengunjung, pelayanan terbaik dari setiap karyawan yang bekerja.

\section{Data Administrasi :}

Surat Izin Kepariwisataan : No. 556.11.45/25-BPPTPM

Alamat $\quad$ : Jl H Achmad Adnawijaya (Pandu Raya) No.11-D, Indraprasta 2 Tegal Gundil, Bogor Utara.

Telpon $\quad: 0251-8351875 / 4721388$

Fax $\quad: 0251-8346182$

Email : : wins.hotel@yahoo.com 


\subsection{Struktur Organisasi dan Uraian Tugas}

Berdasarkan hasil tinjauan yang dilakukan oleh penyusun, maka penyusun dapat menguraikan struktur dan tanggung jawab masing-masing bagian dalam Win's Hotel sebagai berikut :

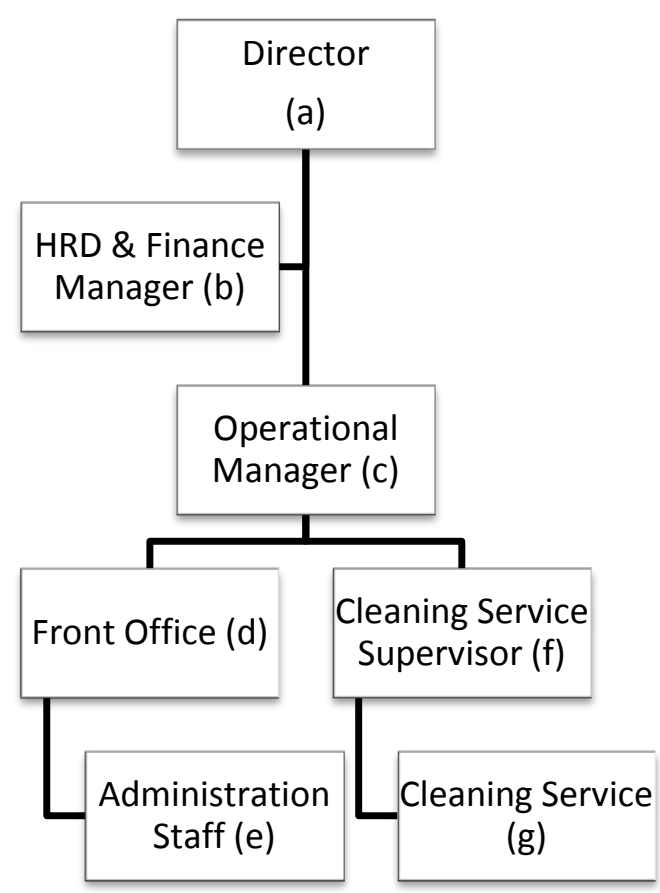

Gambar 3.1 Struktur organisasi Win's Hotel

Sebagaimana yang tertera pada struktur organisasi Win's Hotel diatas, maka tugas dari masing-masing bagian dapat diuraikan sebagai berikut :

(a) Direktur (Director)

- Memimpin perusahaan dengan menerbitkan kebijakan-kebijakan perusahaan

- Membuat kebijakan terkait dengan kegiatan operasional atau kelancaran aktivitas hotel. 
- Merencanakan pengembangan hotel dengan menjalin kerjasama dengan pihak lain.

- Bertindak sebagai pembuat keputusan untuk urusan yang tidak dapat ditangani oleh bawahan.

(b) Manajer Sumber Daya Manusia \& Keuangan (HRD \& Finance Manager)

- Menyeleksi, menempatkan, melatih dan mengevaluasi kinerja dari karyawan hotel.

- Menjaga kedisiplinan karyawan hotel dengan memberikan peringatan dan sanksi bagi yang melanggar ketentuan.

- Memastikan bahwa karyawan mendapatkan pengarahan dan informasi yang cukup mengenai peraturan dan ketentuan hotel, serta standarstandar dalam melayani tamu.

- Menjalankan pembayaran untuk operasional hotel seperti gaji, dan beban perusahaan lainnya.

- Mengurus pengembalian kelebihan pembayaran tamu.

- Menetapkan anggaran pengeluaran operasional hotel.

- Membuat laporan keuangan hotel.

(c) Manajer Operasional (Operational Manager)

- Mengatur jadwal ketersediaan kamar via website online

- Melaporkan jadwal pembayaran tagihan hotel kepada HRD \& Finance Manager.

- Menangani keluhan dari tamu yang tidak dapat diselesaikan oleh bawahannya.

- Mengontrol jalannya kegiatan operasional hotel. 
- Mengontrol dan menganalisa biaya pengeluaran operasional hotel untuk menjamin bahwa pengeluaran tidak melebihi anggaran yang telah ditetapkan.

(d) Resepsionis (Front Office)

- Melayani reservasi dari tamu yang akan menginap di hotel melalui telepon ataupun datang langsung.

- Menangani tamu yang check-in, memenuhi kebutuhan administrasi tamu.

- Memeriksa jadwal ketersediaan kamar yang tersedia.

- Bertanggung jawab atas penjualan kamar

- Menerima uang masuk pembayaran tamu

- Membersihkan lokasi/area dan peralatan

(e) Staf Administrasi (Administration Staff)

- Mengurus pencatatan penjualan kamar serta penjualan makanan \& minuman

- Mencatat pengeluaran kebutuhan harian hotel

- Mencatat jumlah stock laundry hotel yang tersedia

- Melakukan pembelian kebutuhan perlengkapan dan peralatan hotel.

(f) Supervisor Kebersihan (Cleaning Service Supervisor)

- Membuat jadwal shift cleaning sevice staff

- Mengawasi pekerjaan cleaning service staff

- Mengurus absensi cleaning service staff

- Bertanggung jawab terhadap kebersihan seluruh area hotel

- Memberikan penugasan dan arahan kepada cleaning service staff terhadap tugas-tugas yang harus dijalankan 
- Memeriksa kondisi area umum secara teliti. Pemeriksaa kamar harus berdasarkan kebersihan, kerapihan, kelengkapan dan fungsi dari peralatan atau fasilitas yang ada di area masing-masing.

- Menindaklanjuti area-area, fasilitas-fasilitas atau peralatan yang mengalami kerusakan, mengawasi pengerjaan dan memeriksa kembali hasil pengerjaannya.

- Membuat program pelatihan (training program) terhadap cleaning service staff baru

(g) Petugas Kebersihan (Cleaning Service Staff)

- Merawat dan memelihara kebersihan peralatan hotel.

- Bertanggung jawab atas kebersihan, kerapihan dan kelengkapan fasilitas kamar

- Membawakan koper atau barang bawaan tamu

- Melayani permintaan tamu

- Menyiapkan dan mengantarkan sarapan pagi untuk tamu yang menginap di hotel.

- Memeriksa kondisi dan kelengkapan fasilitas hotel pada saat tamu check out.

\subsection{Sumber Daya Manusia}

Sumber Daya Manusia Win's Hotel terdiri dari :

\begin{tabular}{|c|l|c|c|}
\hline No & \multicolumn{1}{|c|}{ Jabatan } & Jumlah & $\begin{array}{c}\text { Jenjang } \\
\text { Pendidikan }\end{array}$ \\
\hline 1 & Director & 1 orang & S2 \\
\hline 2 & HRD \& Finance Manager & 1 orang & S1 \\
\hline 3 & Operational Manager & 1 orang & D3 \\
\hline 4 & Front Office & 2 orang & SMK \\
\hline 5 & Administration Staff & 1 orang & SMK \\
\hline
\end{tabular}




\begin{tabular}{|c|l|c|c|}
\hline 6 & Cleaning Service Supervisor & 1 orang & SMK \\
\hline 7 & Cleaning Service Staff & 4 orang & SMP \\
\hline 8 & Karyawan Tidak Tetap (Security) & 1 orang & SMP \\
\hline
\end{tabular}

\subsection{Sarana dan Prasarana}

Win's Hotel merupakan perusahaan yang bergerak di bidang jasa perhotelan. Sarana dan prasarana yang dimiliki Win's Hotel merupakan salah satu faktor penting yang menunjang kegiatan operasional hotel. Berikut adalah sarana dan prasarana yang dimiliki oleh Win's Hotel :

1. Kamar hotel yang tersedia untuk dijual sejumlah 9 kamar yang terbagi ke dalam 3 tipe kamar, yaitu : Kamar Anggrek, Kamar Mawar, dan Kamar Tulip. Fasilitas yang tersedia untuk setiap kamar hotel adalah Local TV, AC, Kulkas, Shower Bathroom, Water Heater.

2. WiFi pada area Lobby.

3. Tempat parkir bersama di halaman depan hotel.

4. Kendaraan untuk menunjang aktivitas hotel.

5. Peralatan Kantor untuk menunjang kegiatan administrasi hotel, berupa computer, printer, laptop, telepon/fax, meja kerja, dan lainnya.

6. Peralatan hotel untuk menunjang aktivitas hotel seperti : mesin cuci, setrika, vacuum cleaner, alat pemanggang roti, dispenser, cooler, dan sebagainya.

7. Perlengkapan kebersihan seperti sapu, alat pel, cairan pembersih, sabun deterjen, dan sebagainya.

8. Perlengkapan tamu untuk memenuhi kebutuhan tamu (secara gratis) seperti : shampoo tamu, piring \& gelas, makanan dan minuman untuk sarapan.

9. Persediaan Barang Dagangan untuk memenuhi kebutuhan tamu seperti shampoo, odol, sikat gigi, air mineral, makanan ringan dan sebagainya. 


\subsection{Uraian Singkat Kegiatan Penulisan Tugas Akhir}

Dalam usaha untuk mengumpulkan dan mendapatkan data dari perusahaan dalam rangka penyusunan laporan tugas akhir ini, maka kegiatan penyusun adalah sebagai berikut :

1. Mengajukan kepada manajemen agar diberi izin untuk melakukan tinjauan aset tetap pada Win's Hotel.

2. Penyusun mulai melakukan observasi di lapangan dan mengumpulkan data terkait dengan perolehan dan penyusutan asset tetap yang dimiliki oleh perusahaan.

3. Melakukan tanya jawab kepada pegawai yang bersangkutan sebagai bahan tambahan penyusunan tugas akhir.

4. Penyusun mulai membuat tugas akhir berdasarkan data-data yang telah dikumpulkan.

5. Mengelola data bookingan tamu Win's Hotel.

6. Merapikan (filing) data-data administrasi yang berhubungan dengan kegiatan operasional Win's Hotel.

7. Mengurus administrasi dan keuangan yang berhubungan dengan operasional Win's Hotel

\subsection{Perbandingan Teori dan Praktek}

\subsubsection{Pengakuan Aset Tetap pada Win's Hotel}

Pembelian aset yang dilakukan Hotel dilakukan dapat secara tunai ataupun kredit. Harga perolehan aset yang diakui oleh hotel baik untuk pembelian secara tunai maupun kredit adalah sebesar harga transaksi aset atau barang, termasuk biaya ongkos angkut, pemasangan, asuransi sampai aset tersebut dapat digunakan oleh Win's Hotel. 
Aset tetap Win's Hotel meliputi tanah, bangunan hotel, kendaraan, peralatan kantor, dan peralatan hotel.

\section{A. Tanah}

Yaitu tanah yang dimiliki dan dipergunakan untuk menjalankan kegiatan operasional Win's Hotel. Nilai tanah yang diakui adalah sebesar harga tunai pembelian tanah termasuk biaya notaris, komisi perantara, pajak pembeli, biaya BPHTB, biaya balik nama dan sebagainya sampai tanah tersebut diperoleh dan dapat digunakan.

Jurnal yang dibuat pada saat perolehan tanah :

\begin{tabular}{|c|c|c|c|}
\hline Tgl. & Akun & Debit & Kredit \\
\hline \hline 03-Mei-11 & Tanah & 150.000 .000 & \\
\hline & Kas / Bank & & 150.000 .000 \\
\hline
\end{tabular}

B. Bangunan Hotel

Yaitu gedung atau bangunan yang dimiliki serta dipergunakan untuk menjalankan aktivitas Win's Hotel. Nilai bangunan yang diakui oleh Win's Hotel adalah sebesar biaya mulai dari pemerataan tanah hingga konstruksi bangunan selesai,biaya perizinan mendirikan bangunan, termasuk pemasangan / instalasi listrik, pam, water heater dan peralatan di dalam bangunan seperti pembuatan kamar mandi, pemasangan pintu, keramik dinding dan lantai, jendela serta peralatan lainnya hingga bangunan Win's Hotel siap untuk digunakan.

Untuk biaya yang dikeluarkan dalam rangka perbaikan / renovasi yang berjumlah besar tidak diakui sebagai penambah harga perolehan bangunan melainkan dibebankan pada laporan laba rugi periode berjalan.

Jurnal yang dibuat pada saat perolehan tanah dan bangunan : 


\begin{tabular}{|c|c|c|c|}
\hline Tgl. & Akun & Debit & Kredit \\
\hline \hline 03-May-11 & Bangunan & $1,025,000,000$ & \\
& Kas / Bank & & $1,025,000,000$ \\
\hline
\end{tabular}

\section{Kendaraan}

Yaitu kendaraan yang digunakan untuk mendukung kelancaran aktivitas operasional Win's Hotel. Harga perolehan kendaraan dicatat sebesar nilai pembelian termasuk bea balik nama kendaraan, biaya pengurusan STNK dan biaya lainnya sampai kendaraan tersebut diperoleh.

Jurnal yang dibuat pada saat perolehan kendaraan :

\begin{tabular}{|c|c|c|c|}
\hline Tgl. & Akun & Debit & Kredit \\
\hline \hline 10-Mar-11 & Kendaraan & $7,500,000$ & \\
\hline & Kas & & $7,500,000$ \\
\hline
\end{tabular}

\begin{tabular}{|c|c|c|c|}
\hline Tgl. & Akun & Debit & Kredit \\
\hline \hline 05-Apr-11 & Kendaraan & $13,500,000$ & \\
\hline & Kas & & $13,500,000$ \\
\hline
\end{tabular}

D. Peralatan Kantor

Peralatan kantor dicatat sebesar nilai pembelian termasuk instalasi software, dan perangkat lainnya yang menunjang agar peralatan kantor dapat digunakan. Reparasi atau perbaikan setelah perolehan peralatan diakui sebagai beban pemeliharaan / reparasi.

\begin{tabular}{|l|l|c|c|r|}
\hline \multicolumn{2}{|c|}{ Peralatan Kantor } & Qty & Tgl Perolehan & $\begin{array}{c}\text { Harga } \\
\text { Perolehan }\end{array}$ \\
\hline 1 & AC & 1 & $22-F e b-11$ & 3.600 .000 \\
\hline 2 & Meja Kerja set Kursi & 5 & $22-F e b-11$ & 3.932 .500 \\
\hline 3 & Laptop 'Fujitsu' & 1 & $22-F e b-11$ & 6.500 .000 \\
\hline 4 & Telepon & 1 & $22-F e b-11$ & 330.000 \\
\hline
\end{tabular}




\begin{tabular}{|l|l|c|c|r|}
\hline 5 & Telp/Fax & 1 & $22-F e b-11$ & 912.000 \\
\hline 6 & Komputer set perangkat & 1 & $25-$ Feb-11 & 3.150 .000 \\
\hline 7 & Printer 'HP' & 1 & $25-F e b-11$ & 1.700 .000 \\
\hline 8 & Printer 'Epson' & 1 & $09-M e i-12$ & 2.350 .000 \\
\hline 9 & Komputer set perangkat & 1 & $05-$ Mar-13 & 3.550 .000 \\
\hline 10 & Kipas Angin & 1 & $10-A p r-13$ & 449.000 \\
\hline & TOTAL & & & $\mathbf{2 6 . 4 7 3 . 5 0 0}$ \\
\hline
\end{tabular}

Jurnal yang dibuat pada saat perolehan peralatan kantor :

\begin{tabular}{|c|c|c|c|}
\hline Tgl. & Akun & Debit & Kredit \\
\hline \hline 22-Feb-11 & Peralatan Kantor & $15,274,500$ & \\
\hline & Kas & & $15,274,500$ \\
\hline
\end{tabular}

\begin{tabular}{|c|c|c|c|}
\hline Tgl. & Akun & Debit & Kredit \\
\hline \hline 25-Feb-11 & Peralatan Kantor & $4,850,000$ & \\
\hline & Kas & & $4,850,000$ \\
\hline
\end{tabular}

\begin{tabular}{|c|c|c|c|}
\hline Tgl. & Akun & Debit & Kredit \\
\hline \hline 09-May-12 & Peralatan Kantor & $2,350,000$ & \\
\hline & Kas & & $2,350,000$ \\
\hline
\end{tabular}

\begin{tabular}{|c|c|c|c|}
\hline Tgl. & Akun & Debit & Kredit \\
\hline \hline 05-Mar-13 & Peralatan Kantor & $3,550,000$ & \\
\hline & Kas & & $3,550,000$ \\
\hline
\end{tabular}

\begin{tabular}{|c|c|c|c|}
\hline Tgl. & Akun & Debit & Kredit \\
\hline \hline 10-Apr-13 & Peralatan Kantor & 449,000 & \\
\hline & Kas & & 4 \\
\hline
\end{tabular}




\section{E. Peralatan Hotel}

Peralatan Hotel dicatat sebesar harga pembelian peralatan termasuk biaya pemasangan, biaya angkut atau biaya pengiriman serta biaya lainnya sampai peralatan hotel siap untuk digunakan. Biaya yang dikeluarkan setelah perolehan peralatan hotel diakui sebagai beban pemeliharaan atau beban reparasi.

1. Peralatan Hotel - Elektronik

\begin{tabular}{|c|c|c|c|c|}
\hline \multicolumn{2}{|c|}{ Peralatan Hotel - Elektronik } & Qty & $\begin{array}{c}\text { Tgl } \\
\text { Perolehan }\end{array}$ & $\begin{array}{c}\text { Harga } \\
\text { Perolehan }\end{array}$ \\
\hline 1 & Water Heater & 1 & 11-Jan-11 & 28.800 .000 \\
\hline 2 & Kulkas & 5 & 22-Feb-11 & 6.229 .850 \\
\hline 3 & TV & 10 & 22-Feb-11 & 19.750 .000 \\
\hline 4 & $A C$ & 9 & 22-Feb-11 & 28.800 .000 \\
\hline 5 & Toaster & 1 & 22-Feb-11 & 605.000 \\
\hline 6 & Dispenser & 1 & 22-Feb-11 & 1.595 .000 \\
\hline 7 & HP Flexi & 2 & 22-Feb-11 & 518.000 \\
\hline 8 & Cooler Display & 1 & 22-Feb-11 & 1.785 .000 \\
\hline 9 & Telepon set 'Panasonic' & 9 & 24-Feb-11 & 2.331 .000 \\
\hline 10 & Antena TV & 1 & 24-Feb-11 & 190.000 \\
\hline 11 & Vacuum Cleaner & 1 & 02-Mar-11 & 1.358 .000 \\
\hline 12 & Telepon set 'Panasonic' & 1 & 02-Mar-11 & 349.000 \\
\hline 13 & Kamera Digital & 1 & 08-Mar-11 & 2.775 .000 \\
\hline 14 & CCTV set perangkat & 1 & 09-Mei-11 & 6.000 .000 \\
\hline 15 & TV & 2 & 17-Jan-12 & 3.970 .000 \\
\hline 16 & $A C$ & 1 & $17-F e b-12$ & 3.600 .000 \\
\hline 17 & Mesin Cuci & 1 & 19-Apr-12 & 12.988 .500 \\
\hline 18 & Setrika 'Philips' & 1 & 19-Apr-12 & 200.000 \\
\hline 19 & Antena TV & 1 & 14-Mei-13 & 185.000 \\
\hline
\end{tabular}




\begin{tabular}{|l|l|l|l|r|}
\hline 20 & Setrika 'Philips' & 1 & 15-Mei-13 & 200.000 \\
\hline & TOTAL & & & $\mathbf{1 2 2 . 2 2 9 . 3 5 0}$ \\
\hline
\end{tabular}

Jurnal yang dibuat pada saat perolehan peralatan hotel-elektronik :

\begin{tabular}{|c|c|c|c|}
\hline Tgl. & Akun & Debit & Kredit \\
\hline \hline 11-Jan-11 & Peralatan Hotel-Elektronik & 28.800 .000 & \\
\hline & Kas & & 28.800 .000 \\
\hline
\end{tabular}

\begin{tabular}{|c|c|c|c|}
\hline Tgl. & Akun & Debit & Kredit \\
\hline \hline 22-Feb-11 & Peralatan Hotel-Elektronik & 59.282 .850 & \\
\hline & Kas & & 59.282 .850 \\
\hline
\end{tabular}

\begin{tabular}{|c|c|c|c|}
\hline Tgl. & Akun & Debit & Kredit \\
\hline \hline 24-Feb-11 & Peralatan Hotel-Elektronik & 2.521 .000 & \\
\hline & Kas & & 2.521 .000 \\
\hline
\end{tabular}

\begin{tabular}{|c|c|c|c|}
\hline Tgl. & Akun & Debit & Kredit \\
\hline \hline 02-Mar-11 & Peralatan Hotel-Elektronik & 1.707 .000 & \\
\hline & Kas & & 1.707 .000 \\
\hline
\end{tabular}

\begin{tabular}{|c|c|c|c|}
\hline Tgl. & Akun & Debit & Kredit \\
\hline \hline 08-Mar-11 & Peralatan Hotel-Elektronik & 2.775 .000 & \\
\hline & Kas & & 2.775 .000 \\
\hline
\end{tabular}

\begin{tabular}{|c|c|c|c|}
\hline Tgl. & Akun & Debit & Kredit \\
\hline \hline 09-Mei-11 & Peralatan Hotel-Elektronik & 6.000 .000 & \\
\hline & Kas & & 6.000 .000 \\
\hline
\end{tabular}

\begin{tabular}{|c|c|c|c|}
\hline Tgl. & Akun & Debit & Kredit \\
\hline \hline 17-Jan-12 & Peralatan Hotel-Elektronik & 3.970 .000 & \\
\hline & Kas & & 3.970 .000 \\
\hline
\end{tabular}




\begin{tabular}{|c|c|c|c|}
\hline Tgl. & Akun & Debit & Kredit \\
\hline \hline 17-Feb-12 & Peralatan Hotel-Elektronik & 3.600 .000 & \\
\hline & Kas & & 3.600 .000 \\
\hline
\end{tabular}

\begin{tabular}{|c|c|c|c|}
\hline Tgl. & Akun & Debit & Kredit \\
\hline \hline 19-Apr-12 & Peralatan Hotel-Elektronik & 13.188 .500 & \\
\hline & Kas & & 13.188 .500 \\
\hline
\end{tabular}

\begin{tabular}{|c|c|c|c|}
\hline Tgl. & Akun & Debit & Kredit \\
\hline \hline 14-Mei-13 & Peralatan Hotel-Elektronik & 185.000 & \\
\hline & Kas & & 185.000 \\
\hline
\end{tabular}

\begin{tabular}{|c|c|c|c|}
\hline Tgl. & Akun & Debit & Kredit \\
\hline \hline 15-Mei-13 & Peralatan Hotel-Elektronik & 200.000 & \\
\hline & Kas & & 200.000 \\
\hline
\end{tabular}

c. Peralatan Hotel - Perabot

\begin{tabular}{|l|l|c|c|r|}
\hline \multicolumn{2}{|c|}{ Peralatan Hotel - Perabot } & Qty & $\begin{array}{c}\text { Tgl } \\
\text { Perolehan }\end{array}$ & Harga Perolehan \\
\hline 1 & Meja Kerja & 6 & 12-Jan-11 & 8.400 .000 \\
\hline 2 & Bak TV & 9 & 12-Jan-11 & 1.800 .000 \\
\hline 3 & Meja Terbang & 4 & 12-Jan-11 & 600.000 \\
\hline 4 & Meja Bar & 1 & 20-Jan-11 & 8.550 .000 \\
\hline 5 & Kursi Yuyu Kulit & 2 & 20-Jan-11 & 650.000 \\
\hline 6 & Etalase Kaca & 2 & 20-Jan-11 & 3.270 .000 \\
\hline 7 & Sofa Tamu set & 1 & 20-Jan-11 & 5.200 .000 \\
\hline 8 & Standing Lampu & 9 & 22-Feb-11 & 2.722 .500 \\
\hline 9 & Matt/Divan 180 & 5 & 22-Feb-11 & 15.421 .875 \\
\hline 10 & Matt/Divan 160 & 4 & 22-Feb-11 & 11.100 .000 \\
\hline 11 & Tempat Jemuran Handuk & 5 & 22-Feb-11 & 625.000 \\
\hline 12 & Extra Bed & 4 & 02-Mar-11 & 1.800 .000 \\
\hline & TOTAL & & & 60.139 .375 \\
\hline
\end{tabular}


Jurnal yang dibuat pada saat perolehan peralatan hotel-perabot :

\begin{tabular}{|c|c|c|c|}
\hline Tgl. & Akun & Debit & Kredit \\
\hline \hline 12-Jan-11 & Peralatan Hotel-Perabot & 10.800 .000 & \\
\hline & Kas & & 10.800 .000 \\
\hline
\end{tabular}

\begin{tabular}{|c|c|c|c|}
\hline Tgl. & Akun & Debit & Kredit \\
\hline \hline 20-Jan-11 & Peralatan Hotel-Perabot & 17.670 .000 & \\
\hline & Kas & & 17.670 .000 \\
\hline
\end{tabular}

\begin{tabular}{|c|c|c|c|}
\hline Tgl. & Akun & Debit & Kredit \\
\hline \hline 22-Feb-11 & Peralatan Hotel-Perabot & 29.869 .375 & \\
\hline & Kas & & 29.869 .375 \\
\hline
\end{tabular}

\begin{tabular}{|c|c|c|c|}
\hline Tgl. & Akun & Debit & Kredit \\
\hline \hline 02-Mar-11 & Peralatan Hotel-Perabot & 1.800 .000 & \\
\hline & Kas & & 1.800 .000 \\
\hline
\end{tabular}

d. Peralatan Hotel - Kain

\begin{tabular}{|c|c|c|c|c|}
\hline \multicolumn{2}{|r|}{ Peralatan Hotel - Kain } & Qty & Tgl Perolehan & $\begin{array}{c}\text { Harga } \\
\text { Perolehan }\end{array}$ \\
\hline 1 & Bantal & 20 & 22-Feb-11 & 1.500 .000 \\
\hline 2 & Selimut Coklat & 14 & 22-Feb-11 & 3.220 .000 \\
\hline 3 & Matt Protector 180 & 6 & 22-Feb-11 & 1.200 .000 \\
\hline 4 & Matt Protector 160 & 5 & 22-Feb-11 & 900.000 \\
\hline 5 & Sprei set 180 & 15 & 25-Feb-11 & 3.300 .000 \\
\hline 6 & Sprei set 160 & 12 & 25-Feb-11 & 2.280 .000 \\
\hline 7 & Sprei set 90 & 10 & 25-Feb-11 & 1.200 .000 \\
\hline 8 & Handuk & 26 & 25-Feb-11 & 1.430 .000 \\
\hline 9 & Keset Kaki & 20 & 25-Feb-11 & 750.000 \\
\hline 10 & Selimut (Quilt) & 19 & 21-Mar-13 & 5.795 .000 \\
\hline 11 & Duve & 15 & 21-Mar-13 & 2.925 .000 \\
\hline 12 & Bantal & 5 & 20-Mei-13 & 425.000 \\
\hline 13 & Matt Protector 180 & 4 & 20-Mei-13 & 880.000 \\
\hline 14 & Matt Protector 160 & 8 & 20-Mei-13 & 1.600 .000 \\
\hline 15 & Sprei set 180 & 6 & 15-Jun-13 & 1.380 .000 \\
\hline 16 & Sprei set 160 & 10 & 15-Jun-13 & 2.050 .000 \\
\hline 17 & Sprei set 90 & 5 & 15-Jun-13 & 1.200 .000 \\
\hline
\end{tabular}




\begin{tabular}{|r|l|c|c|r|}
\hline 18 & Handuk & 22 & $15-J u n-13$ & 1.265 .000 \\
\hline 19 & Keset Kaki & 6 & $15-J u n-13$ & 213.000 \\
\hline & TOTAL & & & 33.513 .000 \\
\hline
\end{tabular}

Jurnal yang dibuat pada saat perolehan peralatan hotel-kain :

\begin{tabular}{|c|c|c|c|}
\hline Tgl. & Akun & Debit & Kredit \\
\hline \hline 22-Feb-11 & Peralatan Hotel-Kain & 6.820 .000 & \\
\hline & Kas & & 6.820 .000 \\
\hline
\end{tabular}

\begin{tabular}{|c|c|c|c|}
\hline Tgl. & Akun & Debit & Kredit \\
\hline \hline 25-Feb-11 & Peralatan Hotel-Kain & 8.960 .000 & \\
\hline & Kas & & 8.960 .000 \\
\hline
\end{tabular}

\begin{tabular}{|c|c|c|c|}
\hline Tgl. & Akun & Debit & Kredit \\
\hline \hline 21-Mar-13 & Peralatan Hotel-Kain & 8.720 .000 & \\
\hline & Kas & & 8.720 .000 \\
\hline
\end{tabular}

\begin{tabular}{|c|c|c|c|}
\hline Tgl. & Akun & Debit & Kredit \\
\hline \hline 20-Mei-13 & Peralatan Hotel-Kain & 2.905 .000 & \\
\hline & Kas & & 2.905 .000 \\
\hline
\end{tabular}

\begin{tabular}{|c|c|c|c|}
\hline Tgl. & Akun & Debit & Kredit \\
\hline \hline 15-Jun-13 & Peralatan Hotel-Kain & 6.108 .000 & \\
\hline & Kas & & 6.108 .000 \\
\hline
\end{tabular}

Win's Hotel dalam mencatat reparasi aset tetap dalam jumlah besar dimasukkan ke dalam beban perbaikan dan perawatan.

a. Bangunan

Pada tanggal 2 April dan 5 Mei 2014 diadakan penambahan lapisan anti bocor reflecto pada semua lantai kamar mandi dan lantai dak senilai masing-masing $\mathrm{Rp}$ 6.840.000 dan Rp 5.700.000.

Win's Hotel mencatat transaksi ini dengan jurnal : 


\begin{tabular}{|c|l|c|c|}
\hline Tgl & \multicolumn{1}{|c|}{ Akun } & Debit & Kredit \\
\hline \hline 02-Apr-14 & $\begin{array}{l}\text { Beban Perbaikan dan Perawatan } \\
\text { Gedung }\end{array}$ & 6.840 .000 & \\
\hline & Bank & & 6.840 .000 \\
\hline
\end{tabular}

\begin{tabular}{|c|l|c|c|}
\hline Tgl & \multicolumn{1}{|c|}{ Akun } & Debit & Kredit \\
\hline \hline 05-Mei-14 & $\begin{array}{l}\text { Beban Perbaikan dan Perawatan } \\
\text { Gedung }\end{array}$ & 5.700 .000 & \\
\hline & Bank & & 5.700 .000 \\
\hline
\end{tabular}

Sedangkan berdasarkan teori mengenai pengeluaran yang terjadi dalam jumlah besar yang dapat memperpanjang umur manfaat aset tetap bangunan seharusnya dicatat sebagai penambah harga perolehan bangunan dengan jurnal sebagai berikut :

\begin{tabular}{|c|c|c|c|}
\hline Tgl & Akun & Debit & Kredit \\
\hline \hline 02-Apr-14 & Bangunan & 6.840 .000 & \\
\hline & Bank & & 6.840 .000 \\
\hline
\end{tabular}

\begin{tabular}{|c|c|c|c|}
\hline Tgl & Akun & Debit & Kredit \\
\hline \hline 05-Mei-14 & Bangunan & 5.700 .000 & \\
\hline & Bank & & 5.700 .000 \\
\hline
\end{tabular}

b. Kendaraan

Pada tanggal 5 Juni 2013 motor Vega-R diadakan perbaikan dan penggantian pada seluruh bagian-bagiannya. Total biaya perbaikan dan penggantian tersebut senilai $\operatorname{Rp} 476.000$.

Win's Hotel mencatat transaksi ini dengan jurnal :

\begin{tabular}{|c|c|c|c|}
\hline Tgl & \multicolumn{1}{|c|}{ Akun } & Debit & Kredit \\
\hline \hline 05-Jun-13 & $\begin{array}{l}\text { Beban Perbaikan dan Perawatan } \\
\text { Kendaraan }\end{array}$ & 476.000 & \\
\hline & Kas & & 476.000 \\
\hline
\end{tabular}


Sedangkan berdasarkan teori mengenai pengeluaran yang terjadi dalam jumlah besar yang dapat memperpanjang umur manfaat aset tetap kendaraan seharusnya dicatat sebagai penambah harga perolehan kendaraan dengan jurnal sebagai berikut :

\begin{tabular}{|c|c|c|c|}
\hline Tgl & Akun & Debit & Kredit \\
\hline \hline 05-Jun-13 & Kendaraan & 476.000 & \\
\hline & Kas & & 476.000 \\
\hline
\end{tabular}

c. Peralatan Hotel-Elektronik

Pada tanggal 8 Juli 2014 diadakan penggantian layar TV senilai Rp 1.750 .000 untuk TV di area lobby.

Win's Hotel mencatat transaksi ini dengan jurnal :

\begin{tabular}{|c|l|c|c|}
\hline Tgl & Akun & Debit & Kredit \\
\hline \hline 08-Jul-14 & $\begin{array}{l}\text { Beban Perbaikan dan Perawatan } \\
\text { Peralatan Hotel-Elektronik }\end{array}$ & 1.750 .000 & \\
\hline & Bank & & 1.750 .000 \\
\hline
\end{tabular}

Sedangkan berdasarkan teori mengenai pengeluaran yang terjadi dalam jumlah besar yang dapat memperpanjang umur manfaat aset tetap peralatan hotelelektronik TV seharusnya dicatat sebagai penambah harga perolehan dengan jurnal sebagai berikut :

\begin{tabular}{|c|c|c|c|}
\hline Tgl & Akun & Debit & Kredit \\
\hline \hline 08-Jul-14 & Peralatan Hotel Elektronik & 1.750 .000 & \\
\hline & Bank & & 1.750 .000 \\
\hline
\end{tabular}

Pada tanggal 8 Juli 2014 diadakan pembersihan dan penambahan freon pada 10 unit AC senilai Rp 1.250.000.

Win's Hotel mencatat transaksi ini dengan jurnal : 


\begin{tabular}{|c|l|c|c|}
\hline Tgl & \multicolumn{1}{|c|}{ Akun } & Debit & Kredit \\
\hline \hline 23-Apr-14 & $\begin{array}{l}\text { Beban Perbaikan dan Perawatan } \\
\text { Peralatan Hotel-Elektronik }\end{array}$ & 1.250 .000 & \\
\hline & Bank & & 1.250 .000 \\
\hline
\end{tabular}

Sedangkan berdasarkan teori mengenai pengeluaran yang terjadi dalam jumlah besar yang dapat memperpanjang umur manfaat aset tetap peralatan hotelelektronik AC seharusnya dicatat sebagai penambah harga perolehan peralatan hotel-elektronik dengan jurnal sebagai berikut :

\begin{tabular}{|c|c|c|c|}
\hline Tgl & Akun & Debit & Kredit \\
\hline \hline 23-Apr-14 & Peralatan Hotel Elektronik & 1.250 .000 & \\
\hline & Bank & & 1.250 .000 \\
\hline
\end{tabular}

Win's Hotel dalam menentukan masing-masing harga perolehan aset tetapnya telah sesuai dengan Pernyataan Standar Akuntansi Keuangan No. 16 Tahun 2012.

\subsubsection{Metode Penyusutan Aset Tetap}

Berdasarkan tinjauan yang dilakukan oleh penyusun, metode penyusutan yang digunakan oleh Win's Hotel adalah metode garis lurus (straight line method). Metode penyusutan ini ditentukan berdasarkan kebijakan manajemen Win's Hotel, sehingga taksiran umur manfaat dan nilai residu ditentukan berdasarkan perkiraan masa pemakaian aset tetap dan merek dari peralatan kantor atau peralatan hotel yang dibeli.

Beban penyusutan aset hotel dihitung dengan rumus sebagai berikut :

$$
\text { Beban Penyusutan } \quad=\quad \frac{\text { Biaya Perolehan }- \text { Nilai Sisa }}{\text { Umur Ekonomis }}
$$


Keterangan :

a. Biaya Perolehan adalah sebesar harga pembelian aset tetap.

b. Nilai sisa adalah nilai yang diperkirakan akan tetap ada sampai akhir masa manfaat ekonomis aset. Nilai sisa ditentukan sesuai dengan kebijakan manajemen, biasanya berupa persentase dari harga perolehan.

c. Umur ekonomis adalah perkiraan umum.

d. Umur manfaat dari aset yang akan disusutkan. Umur ekonomis ditentukan sesuai dengan kebijakan manajemen.

Penyusutan dilakukan setiap akhir tahun oleh Win's Hotel tanpa memperhitungkan tanggal perolehan aset tetap. Untuk lebih jelasnya, penyusun akan menyajikan cara perhitungan penyusutan aset tetap berdasarkan metode penyusutan yang digunakan oleh Win's Hotel.

\section{A. Bangunan Win's Hotel}

Harga perolehan bangunan hotel adalah Rp.1.025.000.000,- pada tanggal 3 Maret 2011 dengan perkiraan nilai sisa 20\% dari harga perolehan, umur manfaat 20 tahun.

Pencatatan yang dilakukan oleh Win's Hotel adalah sebagai berikut :

$$
\begin{array}{ll}
= & \frac{(1.025 .000 .000-205.000 .000)}{20} \\
= & 41.000 .000
\end{array}
$$

Jurnal penyusutan per tahun adalah :

\begin{tabular}{|c|c|c|c|}
\hline Tgl & Akun & Debit & Kredit \\
\hline \hline 31-Des-11 & Beban Penyusutan-Bangunan & 41.000 .000 & \\
\hline & $\begin{array}{l}\text { Akumulasi Penyusutan- } \\
\text { Bangunan }\end{array}$ & & 41.000 .000 \\
\hline
\end{tabular}


Tabel 3.1

Beban Penyusutan Bangunan per Tahun (dalam Rupiah)

Metode Penyusutan Garis Lurus

\begin{tabular}{|c|c|c|c|c|}
\hline Tahun & $\begin{array}{c}\text { Harga } \\
\text { Perolehan }\end{array}$ & $\begin{array}{c}\text { Beban } \\
\text { Penyusutan }\end{array}$ & $\begin{array}{c}\text { Akumulasi } \\
\text { Penyusutan }\end{array}$ & $\begin{array}{c}\text { Nilai Buku } \\
\text { Akhir Tahun }\end{array}$ \\
\hline 2011 & $1,025,000,000$ & $41,000,000$ & $41,000,000$ & $984,000,000$ \\
\hline 2012 & $1,025,000,000$ & $41,000,000$ & $82,000,000$ & $943,000,000$ \\
\hline 2013 & $1,025,000,000$ & $41,000,000$ & $123,000,000$ & $902,000,000$ \\
\hline 2014 & $1,025,000,000$ & $41,000,000$ & $164,000,000$ & $861,000,000$ \\
\hline 2015 & $1,025,000,000$ & $41,000,000$ & $205,000,000$ & $820,000,000$ \\
\hline 2016 & $1,025,000,000$ & $41,000,000$ & $246,000,000$ & $779,000,000$ \\
\hline 2017 & $1,025,000,000$ & $41,000,000$ & $287,000,000$ & $738,000,000$ \\
\hline 2018 & $1,025,000,000$ & $41,000,000$ & $328,000,000$ & $697,000,000$ \\
\hline 2019 & $1,025,000,000$ & $41,000,000$ & $369,000,000$ & $656,000,000$ \\
\hline 2020 & $1,025,000,000$ & $41,000,000$ & $410,000,000$ & $615,000,000$ \\
\hline 2021 & $1,025,000,000$ & $41,000,000$ & $451,000,000$ & $574,000,000$ \\
\hline 2022 & $1,025,000,000$ & $41,000,000$ & $492,000,000$ & $533,000,000$ \\
\hline 2023 & $1,025,000,000$ & $41,000,000$ & $533,000,000$ & $492,000,000$ \\
\hline 2024 & $1,025,000,000$ & $41,000,000$ & $574,000,000$ & $451,000,000$ \\
\hline 2025 & $1,025,000,000$ & $41,000,000$ & $615,000,000$ & $410,000,000$ \\
\hline 2026 & $1,025,000,000$ & $41,000,000$ & $656,000,000$ & $369,000,000$ \\
\hline 2027 & $1,025,000,000$ & $41,000,000$ & $697,000,000$ & $328,000,000$ \\
\hline 2028 & $1,025,000,000$ & $41,000,000$ & $738,000,000$ & $287,000,000$ \\
\hline 2029 & $1,025,000,000$ & $41,000,000$ & $779,000,000$ & $246,000,000$ \\
\hline 2030 & $1,025,000,000$ & $41,000,000$ & $820,000,000$ & $205,000,000$ \\
\hline & & & & \\
\hline
\end{tabular}

Berdasarkan teori mengenai perhitungan beban penyusutan pada tahun pertama apabila tanggal perolehan bangunan terjadi antara tanggal 1 sampai dengan 15 , maka perhitungan beban penyusutan dihitung dari bulan yang bersangkutan.

Maka perhitungan beban penyusutan bangunan untuk tahun 2011 adalah sebagai berikut :

$\begin{aligned} & \text { Beban Penyusutan } \\ & \text { Bangunan Tahun } \\ & 2011\end{aligned}=\frac{\text { Harga Perolehan - Nilai Sisa }}{\text { Umur Ekonomis }} \times \frac{10}{12}$ 


$$
\begin{aligned}
& =\frac{(1.025 .000 .000-205.000 .000)}{20} \times \frac{10}{12} \\
& =34.166 .667
\end{aligned}
$$

Jurnal penyusutan tahun 2011 adalah :

\begin{tabular}{|c|c|c|c|}
\hline Tgl & Akun & Debit & Kredit \\
\hline \hline 31-Des-11 & Beban Penyusutan-Bangunan & 34.166 .667 & \\
\hline & $\begin{array}{l}\text { Akumulasi Penyusutan- } \\
\text { Bangunan }\end{array}$ & & 34.166 .667 \\
\hline
\end{tabular}

$$
\begin{array}{ll}
\begin{array}{l}
\text { Beban Penyusutan } \\
\text { Bangunan 2012 }
\end{array} & =\frac{\text { Harga Perolehan }- \text { Nilai Sisa }}{\text { Umur Ekonomis }} \\
& =\frac{(1.025 .000 .000-205.000 .000)}{20} \\
& =
\end{array}
$$

Jurnal penyusutan tahun 2012 dan tahun-tahun berikutnya adalah :

\begin{tabular}{|c|c|c|c|}
\hline Tgl & Akun & Debit & Kredit \\
\hline \hline 31-Des-12 & Beban Penyusutan-Bangunan & 41.000 .000 & \\
\hline & $\begin{array}{l}\text { Akumulasi Penyusutan- } \\
\text { Bangunan }\end{array}$ & & 41.000 .000 \\
\hline
\end{tabular}

Tabel 3.2

Beban Penyusutan Bangunan per Tahun (dalam Rupiah) Metode Penyusutan Garis Lurus

\begin{tabular}{|c|c|c|c|c|}
\hline Tahun & $\begin{array}{c}\text { Harga } \\
\text { Perolehan }\end{array}$ & $\begin{array}{c}\text { Beban } \\
\text { Penyusutan }\end{array}$ & $\begin{array}{c}\text { Akumulasi } \\
\text { Penyusutan }\end{array}$ & $\begin{array}{c}\text { Nilai Buku } \\
\text { Akhir Tahun }\end{array}$ \\
\hline 2011 & 1.025 .000 .000 & 34.166 .667 & 34.166 .667 & 990.833 .333 \\
\hline 2012 & 1.025 .000 .000 & 41.000 .000 & 75.166 .667 & 949.833 .333 \\
\hline 2013 & 1.025 .000 .000 & 41.000 .000 & 116.166 .667 & 908.833 .333 \\
\hline
\end{tabular}




\begin{tabular}{|l|l|l|l|l|}
\hline 2014 & 1.025 .000 .000 & 41.000 .000 & 157.166 .667 & 867.833 .333 \\
\hline 2015 & 1.025 .000 .000 & 41.000 .000 & 198.166 .667 & 826.833 .333 \\
\hline 2016 & 1.025 .000 .000 & 41.000 .000 & 239.166 .667 & 785.833 .333 \\
\hline 2017 & 1.025 .000 .000 & 41.000 .000 & 280.166 .667 & 744.833 .333 \\
\hline 2018 & 1.025 .000 .000 & 41.000 .000 & 321.166 .667 & 703.833 .333 \\
\hline 2019 & 1.025 .000 .000 & 41.000 .000 & 362.166 .667 & 662.833 .333 \\
\hline 2020 & 1.025 .000 .000 & 41.000 .000 & 403.166 .667 & 621.833 .333 \\
\hline 2021 & 1.025 .000 .000 & 41.000 .000 & 444.166 .667 & 580.833 .333 \\
\hline 2022 & 1.025 .000 .000 & 41.000 .000 & 485.166 .667 & 539.833 .333 \\
\hline 2023 & 1.025 .000 .000 & 41.000 .000 & 526.166 .667 & 498.833 .333 \\
\hline 2024 & 1.025 .000 .000 & 41.000 .000 & 567.166 .667 & 457.833 .333 \\
\hline 2025 & 1.025 .000 .000 & 41.000 .000 & 608.166 .667 & 416.833 .333 \\
\hline 2026 & 1.025 .000 .000 & 41.000 .000 & 649.166 .667 & 375.833 .333 \\
\hline 2027 & 1.025 .000 .000 & 41.000 .000 & 690.166 .667 & 334.833 .333 \\
\hline 2028 & 1.025 .000 .000 & 41.000 .000 & 731.166 .667 & 293.833 .333 \\
\hline 2029 & 1.025 .000 .000 & 41.000 .000 & 772.166 .667 & 252.833 .333 \\
\hline 2030 & 1.025 .000 .000 & 41.000 .000 & 813.166 .667 & 211.833 .333 \\
\hline
\end{tabular}

\section{B. Kendaraan}

Pada tanggal 10 Maret 2011 dan 5 April 2011, Win's Hotel memperoleh 1 unit Motor Vega-R bekas seharga Rp.7.500.000,- dan 1 unit Motor Supra X baru seharga Rp.13.500.000,- diperkirakan umur ekonomis 5 tahun dengan nilai sisa $10 \%$ dari harga perolehan dari kedua aset tersebut.

Pencatatan yang dilakukan oleh Win's Hotel adalah sebagai berikut : 


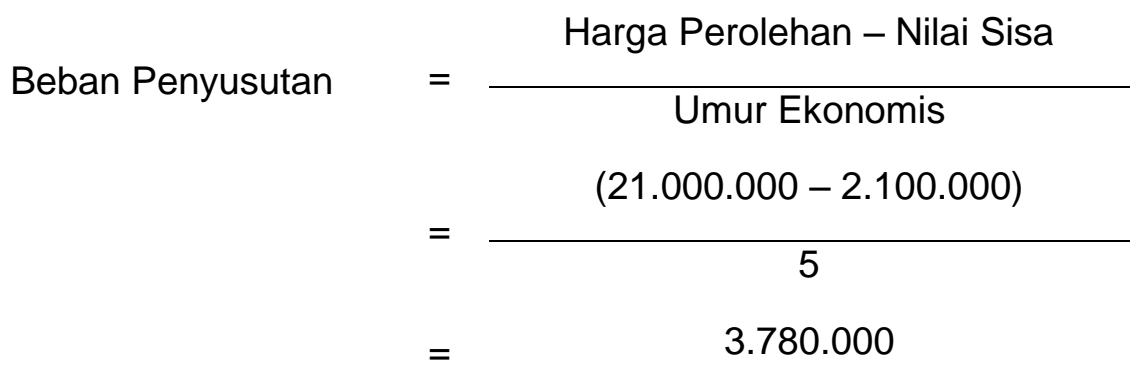

Jurnal penyusutan per tahun adalah :

\begin{tabular}{|c|c|c|c|}
\hline Tgl & Akun & Debit & Kredit \\
\hline \hline 31-Des-11 & Beban Penyusutan-Kendaraan & 3.780 .000 & \\
\hline & $\begin{array}{l}\text { Akumulasi Penyusutan- } \\
\text { Kendaraan }\end{array}$ & & 3.780 .000 \\
\hline
\end{tabular}

Tabel 3.3

Beban Penyusutan Kendaraan per Tahun (dalam Rupiah)

Metode Penyusutan Garis Lurus

\begin{tabular}{|c|r|r|r|r|}
\hline Tahun & $\begin{array}{c}\text { Harga } \\
\text { Perolehan }\end{array}$ & $\begin{array}{c}\text { Beban } \\
\text { Penyusutan }\end{array}$ & $\begin{array}{c}\text { Akumulasi } \\
\text { Penyusutan }\end{array}$ & $\begin{array}{c}\text { Nilai Buku } \\
\text { Akhir Tahun }\end{array}$ \\
\hline 2011 & 21.000 .000 & 3.780 .000 & 3.780 .000 & 17.220 .000 \\
\hline 2012 & 21.000 .000 & 3.780 .000 & 7.560 .000 & 13.440 .000 \\
\hline 2013 & 21.000 .000 & 3.780 .000 & 11.340 .000 & 9.660 .000 \\
\hline 2014 & 21.000 .000 & 3.780 .000 & 15.120 .000 & 5.880 .000 \\
\hline 2015 & 21.000 .000 & 3.780 .000 & 18.900 .000 & 2.100 .000 \\
\hline
\end{tabular}

Berdasarkan teori mengenai perhitungan beban penyusutan pada tahun pertama apabila tanggal perolehan kendaraan terjadi antara tanggal 1 sampai dengan 15 , maka perhitungan beban penyusutan dihitung dari bulan yang bersangkutan.

Maka perhitungan beban penyusutan kendaraan untuk tahun 2011 adalah sebagai berikut :

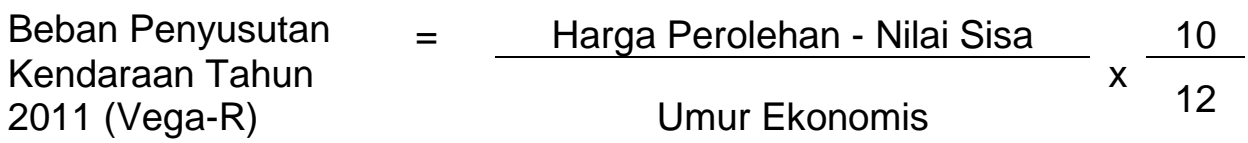




$$
\begin{aligned}
& =\frac{(7.500 .000-750.000)}{5} \times \frac{10}{12} \\
& =1.125 .000
\end{aligned}
$$

Beban Penyusutan Kendaraan Tahun 2011 (Supra-X)

$$
\begin{aligned}
& =\frac{\text { Harga Perolehan }- \text { Nilai Sisa }}{\text { Umur Ekonomis }} \times \frac{9}{12} \\
& =\frac{(13.500 .000-1.350 .000)}{5} \times \frac{9}{12} \\
& =1.822 .500
\end{aligned}
$$

Jurnal penyusutan kendaraan tahun 2011 adalah :

\begin{tabular}{|c|c|c|c|}
\hline Tgl & Akun & Debit & Kredit \\
\hline \hline 31-Des-11 & Beban Penyusutan-Kendaraan & 2.947 .500 & \\
\hline & $\begin{array}{l}\text { Akumulasi Penyusutan- } \\
\text { Kendaraan }\end{array}$ & & 2.947 .500 \\
\hline
\end{tabular}

$\begin{array}{ll}\begin{array}{l}\text { Beban Penyusutan } \\ \text { Kendaraan 2012 }\end{array} & =\frac{\text { Harga Perolehan }- \text { Nilai Sisa }}{\text { Umur Ekonomis }} \\ & =\frac{(21.000 .000-2.100 .000)}{5} \\ & =3.780 .000\end{array}$

Jurnal penyusutan kendaraan tahun 2012 dan tahun-tahun berikutnya adalah :

\begin{tabular}{|c|c|c|c|}
\hline Tgl & Akun & Debit & Kredit \\
\hline \hline 31-Des-12 & Beban Penyusutan-Kendaraan & 3.780 .000 & \\
\hline & $\begin{array}{l}\text { Akumulasi Penyusutan- } \\
\text { Kendaraan }\end{array}$ & & 3.780 .000 \\
\hline
\end{tabular}


Tabel 3.4

Beban Penyusutan Kendaraan per Tahun (dalam Rupiah)

Metode Penyusutan Garis Lurus

\begin{tabular}{|c|r|r|r|r|}
\hline Tahun & $\begin{array}{c}\text { Harga } \\
\text { Perolehan }\end{array}$ & $\begin{array}{c}\text { Beban } \\
\text { Penyusutan }\end{array}$ & $\begin{array}{c}\text { Akumulasi } \\
\text { Penyusutan }\end{array}$ & $\begin{array}{c}\text { Nilai Buku } \\
\text { Akhir Tahun }\end{array}$ \\
\hline 2011 & 21.000 .000 & 2.947 .500 & 2.947 .500 & 18.052 .500 \\
\hline 2012 & 21.000 .000 & 3.780 .000 & 6.727 .500 & 14.272 .500 \\
\hline 2013 & 21.000 .000 & 3.780 .000 & 10.507 .500 & 10.492 .500 \\
\hline 2014 & 21.000 .000 & 3.780 .000 & 14.287 .500 & 6.712 .500 \\
\hline 2015 & 21.000 .000 & 3.780 .000 & 18.067 .500 & 2.932 .500 \\
\hline
\end{tabular}

\section{Peralatan Kantor}

Peralatan kantor Win's Hotel ditaksir memiliki umur ekonomis 5 tahun dengan nilai residu $10 \%$ dari harga perolehan.

\begin{tabular}{|l|l|c|c|r|}
\hline \multicolumn{2}{|l|}{ Peralatan Kantor } & Qty & Tgl Perolehan & Harga Perolehan \\
\hline 1 & AC & 1 & $22-F e b-11$ & 3.600 .000 \\
\hline 2 & Meja Kerja set Kursi & 5 & $22-F e b-11$ & 3.932 .500 \\
\hline 3 & Laptop 'Fujitsu' & 1 & $22-F e b-11$ & 6.500 .000 \\
\hline 4 & Telepon & 1 & $22-F e b-11$ & 330.000 \\
\hline 5 & Telp/Fax & 1 & $22-F e b-11$ & 912.000 \\
\hline 6 & Komputer set perangkat & 1 & $25-F e b-11$ & 3.150 .000 \\
\hline 7 & Printer 'HP' & 1 & $25-F e b-11$ & 1.700 .000 \\
\hline 8 & Printer 'Epson' & 1 & $09-M e i-12$ & 2.350 .000 \\
\hline 9 & Komputer set perangkat & 1 & $05-M a r-13$ & 3.550 .000 \\
\hline 10 & Kipas Angin & 1 & $10-A p r-13$ & 449.000 \\
\hline & TOTAL & & & $\mathbf{2 6 . 4 7 3 . 5 0 0}$ \\
\hline
\end{tabular}

Pencatatan yang dilakukan oleh Win's Hotel adalah sebagai berikut :

Penghitungan beban penyusutan tahun 2011 adalah :

Beban Penyusutan $2011=\frac{\text { Harga Perolehan }- \text { Nilai Sisa }}{\text { Umur Ekonomis }}$ 


$$
\begin{aligned}
& =\frac{(20.124 .500-2.012 .450)}{5} \\
& =\quad 3.622 .410
\end{aligned}
$$

Jurnal penyusutan peralatan kantor pada tahun 2011 adalah :

\begin{tabular}{|c|l|c|c|}
\hline Tgl & \multicolumn{1}{|c|}{ Akun } & Debit & Kredit \\
\hline \hline 31-Des-11 & $\begin{array}{l}\text { Beban Penyusutan-Peralatan } \\
\text { Kantor }\end{array}$ & 3.622 .410 & \\
& $\begin{array}{l}\text { Akumulasi Penyusutan- } \\
\text { Peralatan Kantor }\end{array}$ & & 3.622 .410 \\
\hline
\end{tabular}

Pencatatan penyusutan tambahan aset tahun 2012 adalah sebagai berikut :

$\begin{aligned} \begin{array}{c}\text { Beban Penyusutan } \\ \text { tambahan tahun 2012 }\end{array} & =\frac{\text { Harga Perolehan }- \text { Nilai Sisa }}{\text { Umur Ekonomis }} \\ & =\frac{(2.350 .000-235.000)}{5} \\ & =\end{aligned}$

Jurnal penyusutan peralatan kantor pada tahun 2012 adalah :

\begin{tabular}{|c|c|c|c|}
\hline Tgl & Akun & Debit & Kredit \\
\hline \hline 31-Des-12 & $\begin{array}{c}\text { Beban Penyusutan-Peralatan Kantor } \\
\text { Akumulasi Penyusutan-Peralatan } \\
\text { Kantor }\end{array}$ & 423.000 & \\
\hline
\end{tabular}

Pencatatan penyusutan tahun 2013 adalah sebagai berikut :

Beban Penyusutan tambahan tahun 2013

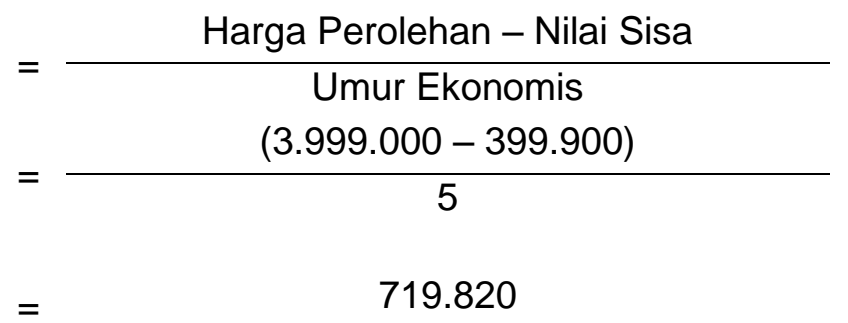

719.820

Jurnal penyusutan peralatan kantor pada tahun 2013 adalah : 


\begin{tabular}{|c|c|c|c|}
\hline Tgl & Akun & Debit & Kredit \\
\hline \hline 31-Des-13 & Beban Penyusutan-Peralatan Kantor & 719.820 & \\
\hline $\begin{array}{l}\text { Akumulasi Penyusutan-Peralatan } \\
\text { Kantor }\end{array}$ & & 719.820 \\
\hline
\end{tabular}

Tabel 3.5

Beban Penyusutan Peralatan Kantor per Tahun (dalam Rupiah)

Metode Penyusutan Garis Lurus

\begin{tabular}{|c|c|c|c|c|}
\hline Tahun & $\begin{array}{c}\text { Harga } \\
\text { Perolehan }\end{array}$ & $\begin{array}{c}\text { Beban } \\
\text { Penyusutan }\end{array}$ & $\begin{array}{c}\text { Akumulasi } \\
\text { Penyusutan }\end{array}$ & $\begin{array}{c}\text { Nilai Buku } \\
\text { Akhir Tahun }\end{array}$ \\
\hline 2011 & 20.124 .500 & 3.622 .410 & 3.622 .410 & 16.502 .090 \\
\hline 2012 & 22.474 .500 & 4.045 .410 & 7.667 .820 & 14.806 .680 \\
\hline 2013 & 26.473 .500 & 4.765 .230 & 12.433 .050 & 14.040 .450 \\
\hline 2014 & 26.473 .500 & 4.765 .230 & 17.198 .280 & 9.275 .220 \\
\hline 2015 & 26.473 .500 & 4.765 .230 & 21.963 .510 & 4.509 .990 \\
\hline 2016 & 26.473 .500 & 1.142 .820 & 23.106 .330 & 3.367 .170 \\
\hline 2017 & 26.473 .500 & 719.820 & 23.826 .150 & 2.647 .350 \\
\hline
\end{tabular}

Berdasarkan teori mengenai perhitungan beban penyusutan pada tahun pertama apabila tanggal perolehan peralatan kantor terjadi antara tanggal 1 sampai dengan 15, maka perhitungan beban penyusutan dihitung dari bulan yang bersangkutan.

Maka perhitungan beban penyusutan kendaraan untuk tahun 2011 adalah sebagai berikut :

Beban Penyusutan = Peralatan Kantor Bulan Feb'11 $=\frac{\text { Harga Perolehan }- \text { Nilai Sisa }}{\text { Umur Ekonomis }} \times \frac{10}{12}$ $=\frac{(20.124 .500-2.012 .450)}{5} \times \frac{10}{12}$ 


$$
=\quad 3.018 .675
$$

Jurnal penyusutan peralatan kantor untuk tahun 2011 adalah :

\begin{tabular}{|c|c|c|c|}
\hline Tgl & Akun & Debit & Kredit \\
\hline \hline 31-Des-11 & Beban Penyusutan-Peralatan Kantor & 3.018 .675 & \\
\hline & $\begin{array}{l}\text { Akumulasi Penyusutan- Peralatan } \\
\text { Kantor }\end{array}$ & & 3.018 .675 \\
\hline
\end{tabular}

Beban Penyusutan Peralatan Kantor Bulan Mei'12

$$
\begin{aligned}
& =\frac{\text { Harga Perolehan - Nilai Sisa }}{\text { Umur Ekonomis }} \times \frac{7}{12} \\
& =\frac{(2.350 .000-235.000)}{5} \times \frac{7}{12} \\
& =246.750
\end{aligned}
$$

Jurnal penyusutan peralatan kantor untuk tahun 2012 adalah :

\begin{tabular}{|c|c|c|c|}
\hline Tgl & Akun & Debit & Kredit \\
\hline \hline 31-Des-12 & Beban Penyusutan-Peralatan Kantor & 276.750 & \\
\hline & $\begin{array}{l}\text { Akumulasi Penyusutan- Peralatan } \\
\text { Kantor }\end{array}$ & & 246.750 \\
\hline
\end{tabular}

Beban Penyusutan Peralatan Kantor Bulan Maret'13

Beban Penyusutan Peralatan Kantor Bulan April'13

$$
\begin{aligned}
& =\frac{\text { Harga Perolehan - Nilai Sisa }}{\text { Umur Ekonomis }} \times \frac{9}{12} \\
& =\frac{(3.550 .000-355.000)}{5} \times \frac{9}{12} \\
& =479.250
\end{aligned}
$$$$
=\frac{\text { Harga Perolehan }- \text { Nilai Sisa }}{\text { Umur Ekonomis }} \times \frac{8}{12}
$$ 
$=$

$\frac{(449.000-44.900)}{5} \times \frac{8}{12}$

Jurnal penyusutan peralatan kantor untuk tahun 2013 adalah :

\begin{tabular}{|c|c|c|c|}
\hline Tgl & Akun & Debit & Kredit \\
\hline \hline 31-Des-13 & Beban Penyusutan-Peralatan Kantor & 533.130 & \\
\hline & $\begin{array}{l}\text { Akumulasi Penyusutan- Peralatan } \\
\text { Kantor }\end{array}$ & & 533.130 \\
\hline
\end{tabular}

Tabel 3.6

Beban Penyusutan Peralatan Kantor per Tahun (dalam Rupiah)

Metode Penyusutan Garis Lurus

\begin{tabular}{|c|c|c|c|c|}
\hline Tahun & $\begin{array}{c}\text { Harga } \\
\text { Perolehan }\end{array}$ & $\begin{array}{c}\text { Beban } \\
\text { Penyusutan }\end{array}$ & $\begin{array}{c}\text { Akumulasi } \\
\text { Penyusutan }\end{array}$ & $\begin{array}{c}\text { Nilai Buku } \\
\text { Akhir Tahun }\end{array}$ \\
\hline 2011 & 20.124 .500 & 3.018 .675 & 3.018 .675 & 17.105 .825 \\
\hline 2012 & 22.474 .500 & 3.869 .160 & 6.887 .835 & 15.586 .665 \\
\hline 2013 & 26.473 .500 & 4.524 .660 & 11.412 .495 & 15.061 .005 \\
\hline 2014 & 26.473 .500 & 4.684 .410 & 16.096 .905 & 10.376 .595 \\
\hline 2015 & 26.473 .500 & 4.684 .410 & 20.781 .315 & 5.692 .185 \\
\hline 2016 & 26.473 .500 & 4.684 .410 & 25.465 .725 & 1.007 .775 \\
\hline 2017 & 26.473 .500 & 4.684 .410 & 30.150 .135 & $(3.676 .635)$ \\
\hline
\end{tabular}

\section{Peralatan Hotel}

Peralatan Hotel diperkirakan memiliki nilai residu dan umur ekonomis sebagai berikut : 
- Elektronik : Nilai residu 10\%, umur ekonomis 5 tahun.

- Perabot : Nilai residu $10 \%$, umur manfaat 8 tahun.

- Kain $\quad$ : Nilai residu 5\%, umur manfaat 3 tahun.

Rincian Peralatan Hotel (Elektronik) adalah sebagai berikut :

\begin{tabular}{|c|c|c|c|c|}
\hline \multicolumn{2}{|r|}{ Peralatan Hotel - Elektronik } & \multirow{2}{*}{$\frac{\text { Qty }}{1}$} & \multirow{2}{*}{$\begin{array}{c}\begin{array}{c}\text { Tgl } \\
\text { Perolehan }\end{array} \\
\text { 11-Jan-11 } \\
\end{array}$} & \multirow{2}{*}{$\begin{array}{r}\text { Harga Perolehan } \\
28.800 .000\end{array}$} \\
\hline 1 & Water Heater & & & \\
\hline 2 & Kulkas & 5 & 22-Feb-11 & 6.229 .850 \\
\hline 3 & TV & 10 & 22-Feb-11 & 19.750 .000 \\
\hline 4 & $\mathrm{AC}$ & 9 & 22-Feb-11 & 28.800 .000 \\
\hline 5 & Toaster & 1 & 22-Feb-11 & 605.000 \\
\hline 6 & Dispenser & 1 & 22-Feb-11 & 1.595 .000 \\
\hline 7 & HP Flexi & 2 & 22-Feb-11 & 518.000 \\
\hline 8 & Cooler Display & 1 & 22-Feb-11 & 1.785 .000 \\
\hline 9 & Telepon set 'Panasonic' & 9 & 24-Feb-11 & 2.331 .000 \\
\hline 10 & Antena TV & 1 & 24-Feb-11 & 190.000 \\
\hline 11 & Vacuum Cleaner & 1 & 02-Mar-11 & 1.358 .000 \\
\hline 12 & Telepon set 'Panasonic' & 1 & 02-Mar-11 & 349.000 \\
\hline 13 & Kamera Digital & 1 & 08-Mar-11 & 2.775 .000 \\
\hline 14 & CCTV set perangkat & 1 & 09-Mei-11 & 6.000 .000 \\
\hline 15 & TV & 2 & 17-Jan-12 & 3.970 .000 \\
\hline 16 & $\mathrm{AC}$ & 1 & $17-F e b-12$ & 3.600 .000 \\
\hline 17 & Mesin Cuci & 1 & 19-Apr-12 & 12.988 .500 \\
\hline 18 & Setrika 'Philips' & 1 & 19-Apr-12 & 200.000 \\
\hline 19 & Antena TV & 1 & 14-Mei-13 & 185.000 \\
\hline 20 & Setrika 'Philips' & 1 & 15-Mei-13 & 200.000 \\
\hline & TOTAL & & & 122.229.350 \\
\hline
\end{tabular}

Pencatatan penyusutan peralatan hotel-elektronik tahun 2011 adalah sebagai berikut :

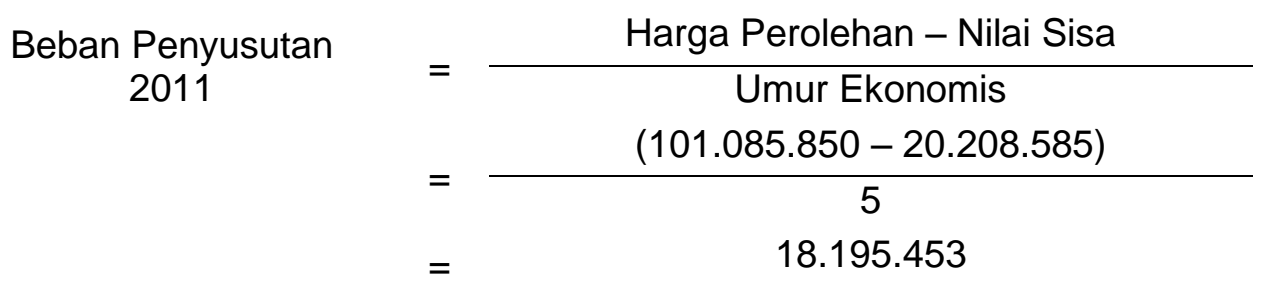


Jurnal penyusutan peralatan hotel-elektronik pada tahun 2011 adalah :

\begin{tabular}{|c|l|c|c|}
\hline Tgl & \multicolumn{1}{|c|}{ Akun } & Debit & Kredit \\
\hline \hline 31-Des-11 & $\begin{array}{l}\text { Beban Penyusutan-Peralatan Hotel- } \\
\text { Elektronik }\end{array}$ & 18.195 .453 & \\
\hline & $\begin{array}{l}\text { Akumulasi Penyusutan-Peralatan } \\
\text { Peralatan Hotel-Elektronik }\end{array}$ & & 18.195 .453 \\
\hline
\end{tabular}

Pencatatan tambahan penyusutan peralatan hotel-elektronik tahun 2012 adalah sebagai berikut :

Beban Penyusutan aset tambahan 2012

$=\frac{\text { Harga Perolehan - Nilai Sisa }}{\text { Umur Ekonomis }}$
$=\frac{(20.758 .500-2.075 .850)}{5}$
$=\quad 3.736 .530$

Jurnal penyusutan peralatan hotel-elektronik pada tahun 2012 adalah :

\begin{tabular}{|c|l|c|c|}
\hline Tgl & \multicolumn{1}{|c|}{ Akun } & Debit & Kredit \\
\hline \hline 31-Des-12 & $\begin{array}{l}\text { Beban Penyusutan-Peralatan Hotel- } \\
\text { Elektronik }\end{array}$ & 3.736 .530 & \\
\hline & $\begin{array}{l}\text { Akumulasi Penyusutan-Peralatan } \\
\text { Peralatan Hotel-Elektronik }\end{array}$ & & 3.736 .530 \\
\hline
\end{tabular}

Pencatatan tambahan penyusutan peralatan hotel-elektronik tahun 2013 adalah sebagai berikut :

Beban Penyusutan aset tambahan 2013

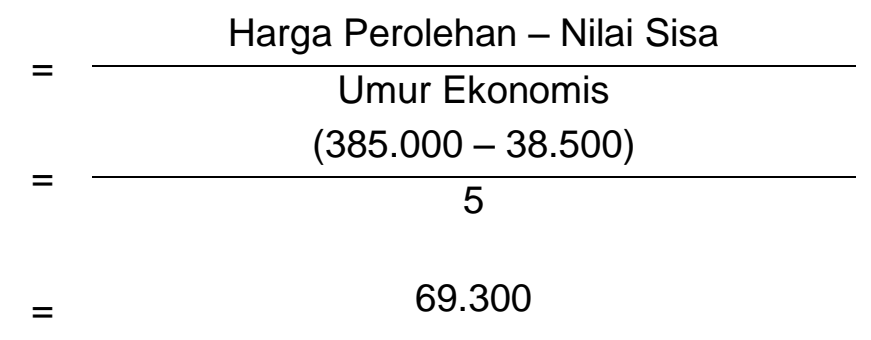

Jurnal penyusutan peralatan hotel-elektronik pada tahun 2013 adalah : 


\begin{tabular}{|c|l|l|l|}
\hline Tgl & \multicolumn{1}{|c|}{ Akun } & Debit & Kredit \\
\hline \hline 31-Des-13 & $\begin{array}{l}\text { Beban Penyusutan-Peralatan Hotel- } \\
\text { Elektronik }\end{array}$ & 69.300 & \\
\hline & $\begin{array}{l}\text { Akumulasi Penyusutan-Peralatan } \\
\text { Peralatan Hotel-Elektronik }\end{array}$ & & 69.300 \\
\hline
\end{tabular}

Tabel 3.7

Beban Penyusutan Peralatan Hotel - Elektronik per Tahun (dalam Rupiah)

Metode Penyusutan Garis Lurus

\begin{tabular}{|c|c|c|c|c|}
\hline Tahun & $\begin{array}{c}\text { Harga } \\
\text { Perolehan }\end{array}$ & $\begin{array}{c}\text { Beban } \\
\text { Penyusutan }\end{array}$ & $\begin{array}{c}\text { Akumulasi } \\
\text { Penyusutan }\end{array}$ & $\begin{array}{c}\text { Nilai Buku } \\
\text { Akhir Tahun }\end{array}$ \\
\hline 2011 & 101.085 .850 & 18.195 .453 & 18.195 .453 & 82.890 .397 \\
\hline 2012 & 121.844 .350 & 21.931 .983 & 40.127 .436 & 81.716 .914 \\
\hline 2013 & 122.229 .350 & 22.001 .283 & 62.128 .719 & 60.100 .631 \\
\hline 2014 & 122.229 .350 & 22.001 .283 & 84.130 .002 & 38.099 .348 \\
\hline 2015 & 122.229 .350 & 22.001 .283 & 106.131 .285 & 16.098 .065 \\
\hline 2016 & 122.229 .350 & 3.805 .830 & 109.937 .115 & 12.292 .235 \\
\hline 2017 & 122.229 .350 & 69.300 & 110.006 .415 & 12.222 .935 \\
\hline
\end{tabular}

Berdasarkan teori mengenai perhitungan beban penyusutan pada tahun pertama apabila tanggal perolehan peralatan hotel-elektronik terjadi antara tanggal 1 sampai dengan 15, maka perhitungan beban penyusutan dihitung dari bulan yang bersangkutan.

Maka perhitungan beban penyusutan peralatan hotel-elektronik untuk tahun 2011 adalah sebagai berikut :

Beban Penyusutan = Peralatan Hotel-

Elektronik Bulan Jan'11

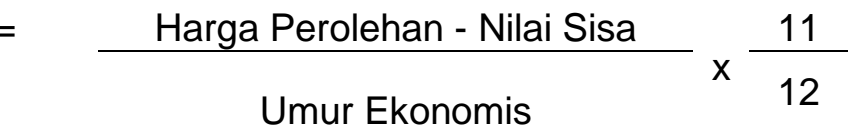




$$
=\frac{(28.800 .000-2.880 .000)}{5} \times \frac{11}{12}
$$

$=\quad 4.752 .000$

Beban Penyusutan
$\begin{aligned} & \text { Peralatan Hotel-Elektronik } \\ & \text { Bulan Februari } 2011\end{aligned}=\quad$ Uarga Perolehan - Nilai Sisa
Umur Ekonomis

$$
\begin{aligned}
& =\frac{(61.803 .850-6.180 .385)}{5} \times \frac{10}{12} \\
& =9.270 .578
\end{aligned}
$$

Beban Penyusutan Peralatan Hotel-Elektronik Bulan Maret 2011 $=\frac{\text { Harga Perolehan }- \text { Nilai Sisa }}{\text { Umur Ekonomis }} \times \frac{9}{12}$

$$
\begin{aligned}
& =\frac{(4.482 .000-448.200)}{5} \times \frac{9}{12} \\
& =605.070
\end{aligned}
$$

Beban Penyusutan
Peralatan Hotel-Elektronik Bulan Mei 2011

$$
\begin{aligned}
& =\frac{\text { Harga Perolehan - Nilai Sisa }}{\text { Umur Ekonomis }} \times \frac{7}{12} \\
& =\frac{(6.000 .000-600.000)}{5} \times \frac{7}{12}
\end{aligned}
$$$$
=630.000
$$

Jurnal penyusutan peralatan hotel-elektronik pada tahun 2011 adalah :

\begin{tabular}{|c|c|c|c|}
\hline Tgl & \multicolumn{1}{|c|}{ Akun } & Debit & Kredit \\
\hline \hline 31-Des-11 & $\begin{array}{l}\text { Beban Penyusutan-Peralatan Hotel- } \\
\text { Elektronik }\end{array}$ & 15.257 .648 & \\
\hline & $\begin{array}{l}\text { Akumulasi Penyusutan-Peralatan } \\
\text { Peralatan Hotel-Elektronik }\end{array}$ & & 15.257 .648 \\
\hline
\end{tabular}


Perhitungan beban penyusutan peralatan hotel-elektronik untuk tahun 2012 adalah sebagai berikut : Beban Penyusutan
$\begin{aligned} & \text { Peralatan Hotel-Elektronik } \\ & \text { Bulan Januari } 2012\end{aligned}=\quad$ Uarga Perolehan - Nilai Sisa
Umur Ekonomis

$$
\begin{aligned}
& =\frac{(3.970 .000-397.000)}{5} \times \frac{11}{12} \\
& =655.050
\end{aligned}
$$

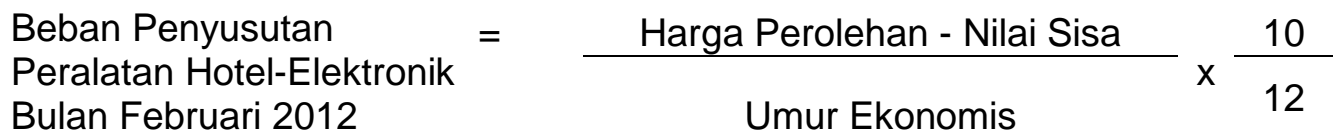

$$
\begin{aligned}
& =\frac{(3.600 .000-360.000)}{5} \times \frac{10}{12} \\
& =540.000
\end{aligned}
$$

Beban Penyusutan Peralatan Hotel-Elektronik Bulan April 2012

$$
\begin{aligned}
& =\frac{\text { Harga Perolehan - Nilai Sisa }}{\text { Umur Ekonomis }} \times \frac{8}{12} \\
& =\frac{(13.188 .500-1.318 .850)}{5} \times \frac{8}{12} \\
& =1.582 .620
\end{aligned}
$$

Jurnal penyusutan peralatan hotel-elektronik pada tahun 2012 adalah :

\begin{tabular}{|c|c|c|c|}
\hline Tgl & Akun & Debit & Kredit \\
\hline \hline 31-Des-12 & $\begin{array}{l}\text { Beban Penyusutan-Peralatan Hotel- } \\
\text { Elektronik }\end{array}$ & 2.777 .670 & \\
\hline & $\begin{array}{l}\text { Akumulasi Penyusutan-Peralatan } \\
\text { Peralatan Hotel-Elektronik }\end{array}$ & & 2.777 .670 \\
\hline
\end{tabular}

Perhitungan beban penyusutan peralatan hotel-elektronik untuk tahun 2013 adalah sebagai berikut : 
Beban Penyusutan
Peralatan Hotel-Elektronik Bulan Mei 2013 $=\frac{\text { Harga Perolehan - Nilai Sisa }}{\text { Umur Ekonomis }} \times \frac{7}{12}$

$$
\begin{aligned}
& =\frac{(385.000-38.500)}{5} \times \frac{7}{12} \\
& =40.425
\end{aligned}
$$

Jurnal penyusutan peralatan hotel-elektronik pada tahun 2013 adalah :

\begin{tabular}{|c|c|c|c|}
\hline Tgl & \multicolumn{1}{|c|}{ Akun } & Debit & Kredit \\
\hline \hline 31-Des-13 & $\begin{array}{l}\text { Beban Penyusutan-Peralatan Hotel- } \\
\text { Elektronik }\end{array}$ & 40.425 & \\
\hline & $\begin{array}{l}\text { Akumulasi Penyusutan-Peralatan } \\
\text { Peralatan Hotel-Elektronik }\end{array}$ & & \\
& & 40.425 \\
\hline
\end{tabular}

Tabel 3.8

Beban Penyusutan Peralatan Hotel - Elektronik per Tahun (dalam Rupiah) Metode Penyusutan Garis Lurus

\begin{tabular}{|c|c|r|r|r|}
\hline Tahun & $\begin{array}{c}\text { Harga } \\
\text { Perolehan }\end{array}$ & $\begin{array}{c}\text { Beban } \\
\text { Penyusutan }\end{array}$ & $\begin{array}{c}\text { Akumulasi } \\
\text { Penyusutan }\end{array}$ & $\begin{array}{c}\text { Nilai Buku } \\
\text { Akhir Tahun }\end{array}$ \\
\hline 2011 & 101.085 .850 & 18.195 .453 & 18.195 .453 & 82.890 .397 \\
\hline 2012 & 121.844 .350 & 20.973 .123 & 39.168 .576 & 82.675 .774 \\
\hline 2013 & 122.229 .350 & 21.972 .408 & 61.140 .984 & 61.088 .366 \\
\hline 2014 & 122.229 .350 & 22.001 .283 & 83.142 .267 & 39.087 .083 \\
\hline 2015 & 122.229 .350 & 22.001 .283 & 105.143 .550 & 17.085 .800 \\
\hline 2016 & 122.229 .350 & 22.001 .283 & 127.144 .833 & $(4.915 .483)$ \\
\hline 2017 & 122.229 .350 & 22.001 .283 & 149.146 .116 & $(26.916 .766)$ \\
\hline
\end{tabular}


Rincian Peralatan Hotel (Perabot) adalah sebagai berikut :

\begin{tabular}{|l|l|c|c|r|}
\hline \multicolumn{2}{|c|}{ Peralatan Hotel - Perabot } & Qty & $\begin{array}{c}\text { Tgl } \\
\text { Perolehan }\end{array}$ & Harga Perolehan \\
\hline 1 & Meja Kerja & 6 & 12-Jan-11 & 8.400 .000 \\
\hline 2 & Bak TV & 9 & 12-Jan-11 & 1.800 .000 \\
\hline 3 & Meja Terbang & 4 & 12-Jan-11 & 600.000 \\
\hline 4 & Meja Bar & 1 & 20-Jan-11 & 8.550 .000 \\
\hline 5 & Kursi Yuyu Kulit & 2 & 20-Jan-11 & 650.000 \\
\hline 6 & Etalase Kaca & 2 & 20-Jan-11 & 3.270 .000 \\
\hline 7 & Sofa Tamu set & 1 & 20-Jan-11 & 5.200 .000 \\
\hline 8 & Standing Lampu & 9 & 22-Feb-11 & 2.722 .500 \\
\hline 9 & Matt/Divan 180 & 5 & 22-Feb-11 & 15.421 .875 \\
\hline 10 & Matt/Divan 160 & 4 & 22-Feb-11 & 11.100 .000 \\
\hline 11 & Tempat Jemuran Handuk & 5 & 22-Feb-11 & 625.000 \\
\hline 12 & Extra Bed & 4 & 02-Mar-11 & 1.800 .000 \\
\hline & TOTAL & & & 60.139 .375 \\
\hline
\end{tabular}

Pencatatan yang dilakukan oleh Win's Hotel adalah sebagai berikut :

Penghitungan beban penyusutan peralatan hotel-perabot tahun 2011 adalah :

Beban Penyusutan 2011
Harga Perolehan - Nilai Sisa

$=\frac{\text { Umur Ekonomis }}{(60.139 .375-6.013 .938)}$
$=\frac{8}{}$

6.765 .680

Jurnal penyusutan peralatan hotel-perabot pada tahun 2011 adalah :

\begin{tabular}{|c|l|c|c|}
\hline Tgl & \multicolumn{1}{|c|}{ Akun } & Debit & Kredit \\
\hline \hline 31-Des-11 & $\begin{array}{l}\text { Beban Penyusutan-Peralatan Hotel- } \\
\text { Perabot }\end{array}$ & 6.765 .680 & \\
\hline & $\begin{array}{l}\text { Akumulasi Penyusutan-Peralatan } \\
\text { Peralatan Hotel-Perabot }\end{array}$ & & 6.765 .680 \\
\hline
\end{tabular}


Tabel 3.9

Beban Penyusutan Peralatan Hotel - Perabot per Tahun (dalam Rupiah) Metode Penyusutan Garis Lurus

\begin{tabular}{|c|c|c|c|c|}
\hline Tahun & $\begin{array}{c}\text { Harga } \\
\text { Perolehan }\end{array}$ & $\begin{array}{c}\text { Beban } \\
\text { Penyusutan }\end{array}$ & $\begin{array}{c}\text { Akumulasi } \\
\text { Penyusutan }\end{array}$ & $\begin{array}{c}\text { Nilai Buku } \\
\text { Akhir Tahun }\end{array}$ \\
\hline 2011 & 60.139 .375 & 6.765 .680 & 6.765 .680 & 53.373 .695 \\
\hline 2012 & 60.139 .375 & 6.765 .680 & 13.531 .359 & 46.608 .016 \\
\hline 2013 & 60.139 .375 & 6.765 .680 & 20.297 .039 & 39.842 .336 \\
\hline 2014 & 60.139 .375 & 6.765 .680 & 27.062 .719 & 33.076 .656 \\
\hline 2015 & 60.139 .375 & 6.765 .680 & 33.828 .398 & 26.310 .977 \\
\hline 2016 & 60.139 .375 & 6.765 .680 & 40.594 .078 & 19.545 .297 \\
\hline 2017 & 60.139 .375 & 6.765 .680 & 47.359 .758 & 12.779 .617 \\
\hline 2018 & 60.139 .375 & 6.765 .680 & 54.125 .438 & 6.013 .938 \\
\hline
\end{tabular}

Berdasarkan teori mengenai perhitungan beban penyusutan pada tahun pertama apabila tanggal perolehan peralatan hotel-perabot terjadi antara tanggal 1 sampai dengan 15, maka perhitungan beban penyusutan dihitung dari bulan yang bersangkutan.

Maka perhitungan beban penyusutan peralatan hotel-perabot untuk tahun 2011 adalah sebagai berikut : $\begin{aligned} & \text { Beban Penyusutan } \\ & \begin{array}{l}\text { Peralatan Hotel-Perabot } \\ \text { Bulan Januari 2011 }\end{array}=\quad \text { Harga Perolehan - Nilai Sisa }\end{aligned} \times \frac{11}{12}$

$$
\begin{aligned}
& =\frac{(28.470 .000-2.847 .000)}{8} \times \frac{11}{12} \\
& =2.935 .969
\end{aligned}
$$


Beban Penyusutan = Peralatan Hotel-Perabot Bulan Februari 2011 $=\frac{\text { Harga Perolehan }- \text { Nilai Sisa }}{\text { Umur Ekonomis }} \times \frac{10}{12}$

$$
\begin{aligned}
& =\frac{(29.869 .375-2.986 .938)}{8} \times \frac{10}{12} \\
& =2.800 .254
\end{aligned}
$$

Beban Penyusutan = Peralatan Hotel-Perabot Bulan Maret 2011

$\frac{\text { Harga Perolehan - Nilai Sisa }}{\text { Umur Ekonomis }} \times \frac{9}{12}$

$$
\begin{aligned}
& =\frac{(180.000-18.000)}{8} \times \frac{9}{12} \\
& =15.188
\end{aligned}
$$

Jurnal penyusutan peralatan hotel-perabot pada tahun 2011 adalah :

\begin{tabular}{|c|l|c|c|}
\hline Tgl & \multicolumn{1}{|c|}{ Akun } & Debit & Kredit \\
\hline \hline 31-Des-11 & $\begin{array}{l}\text { Beban Penyusutan-Peralatan Hotel- } \\
\text { Perabot }\end{array}$ & 5.751 .410 & \\
\hline & $\begin{array}{l}\text { Akumulasi Penyusutan-Peralatan } \\
\text { Peralatan Hotel- Perabot }\end{array}$ & & 5.751 .410 \\
\hline
\end{tabular}

Tabel 3.10

Beban Penyusutan Peralatan Hotel - Perabot per Tahun (dalam Rupiah) Metode Penyusutan Garis Lurus

\begin{tabular}{|c|c|c|c|c|}
\hline Tahun & $\begin{array}{c}\text { Harga } \\
\text { Perolehan }\end{array}$ & $\begin{array}{c}\text { Beban } \\
\text { Penyusutan }\end{array}$ & $\begin{array}{c}\text { Akumulasi } \\
\text { Penyusutan }\end{array}$ & $\begin{array}{c}\text { Nilai Buku Akhir } \\
\text { Tahun }\end{array}$ \\
\hline 2011 & 60.139 .375 & 5.751 .410 & 5.751 .410 & 54.387 .965 \\
\hline 2012 & 60.139 .375 & 6.583 .430 & 12.334 .840 & 47.804 .535 \\
\hline 2013 & 60.139 .375 & 6.583 .430 & 18.918 .270 & 41.221 .105 \\
\hline & & & & \\
\hline
\end{tabular}




\begin{tabular}{|l|l|l|l|l|}
\hline 2014 & 60.139 .375 & 6.583 .430 & 25.501 .699 & 34.637 .676 \\
\hline 2015 & 60.139 .375 & 6.583 .430 & 32.085 .129 & 28.054 .246 \\
\hline 2016 & 60.139 .375 & 6.583 .430 & 38.668 .559 & 21.470 .816 \\
\hline 2017 & 60.139 .375 & 6.583 .430 & 45.251 .988 & 14.887 .387 \\
\hline 2018 & 60.139 .375 & 6.583 .430 & 51.835 .418 & 8.303 .957 \\
\hline
\end{tabular}

Rincian Peralatan Hotel (Kain) adalah sebagai berikut :

\begin{tabular}{|c|c|c|c|c|}
\hline \multicolumn{2}{|r|}{ Peralatan Hotel - Kain } & \multirow{2}{*}{$\frac{\text { Qty }}{20}$} & \multirow{2}{*}{$\begin{array}{c}\text { Tgl Perolehan } \\
22-\text { Feb-11 } \\
\end{array}$} & \multirow{2}{*}{$\begin{array}{c}\begin{array}{c}\text { Harga } \\
\text { Perolehan }\end{array} \\
1.500 .000 \\
\end{array}$} \\
\hline 1 & Bantal & & & \\
\hline 2 & Selimut Coklat & 14 & 22-Feb-11 & 3.220 .000 \\
\hline 3 & Matt Protector 180 & 6 & 22-Feb-11 & 1.200 .000 \\
\hline 4 & Matt Protector 160 & 5 & 22-Feb-11 & 900.000 \\
\hline 5 & Sprei set 180 & 15 & 25-Feb-11 & 3.300 .000 \\
\hline 6 & Sprei set 160 & 12 & 25-Feb-11 & 2.280 .000 \\
\hline 7 & Sprei set 90 & 10 & 25-Feb-11 & 1.200 .000 \\
\hline 8 & Handuk & 26 & 25-Feb-11 & 1.430 .000 \\
\hline 9 & Keset Kaki & 20 & 25-Feb-11 & 750.000 \\
\hline 10 & Selimut (Quilt) & 19 & 21-Mar-13 & 5.795 .000 \\
\hline 11 & Duve & 15 & 21-Mar-13 & 2.925 .000 \\
\hline 12 & Bantal & 5 & 20-Mei-13 & 425.000 \\
\hline 13 & Matt Protector 180 & 4 & 20-Mei-13 & 880.000 \\
\hline 14 & Matt Protector 160 & 8 & 20-Mei-13 & 1.600 .000 \\
\hline 15 & Sprei set 180 & 6 & 15-Jun-13 & 1.380 .000 \\
\hline 16 & Sprei set 160 & 10 & 15-Jun-13 & 2.050 .000 \\
\hline 17 & Sprei set 90 & 5 & 15-Jun-13 & 1.200 .000 \\
\hline 18 & Handuk & 22 & 15-Jun-13 & 1.265 .000 \\
\hline 19 & Keset Kaki & 6 & 15-Jun-13 & 213.000 \\
\hline & TOTAL & & & 33.513 .000 \\
\hline
\end{tabular}

Pencatatan yang dilakukan oleh Win's Hotel adalah sebagai berikut:

Penghitungan beban penyusutan peralatan hotel-kain tahun 2011 adalah :

Beban Penyusutan
2011

Harga Perolehan - Nilai Sisa
$=$
Umur Ekonomis




$$
\begin{array}{cc}
= & \frac{(15.780 .000-789.000)}{3} \\
= & 4.997 .000
\end{array}
$$

Jurnal penyusutan peralatan hotel-kain pada tahun 2011 adalah :

\begin{tabular}{|c|l|c|c|}
\hline Tgl & \multicolumn{1}{|c|}{ Akun } & Debit & Kredit \\
\hline \hline 31-Des-11 & $\begin{array}{l}\text { Beban Penyusutan-Peralatan Hotel- } \\
\text { Kain }\end{array}$ & 4.997 .000 & \\
\hline & $\begin{array}{l}\text { Akumulasi Penyusutan-Peralatan } \\
\text { Peralatan Hotel- Kain }\end{array}$ & & 4.997 .000 \\
\hline
\end{tabular}

Pencatatan tambahan penyusutan peralatan hotel-kain tahun 2013 adalah sebagai berikut :
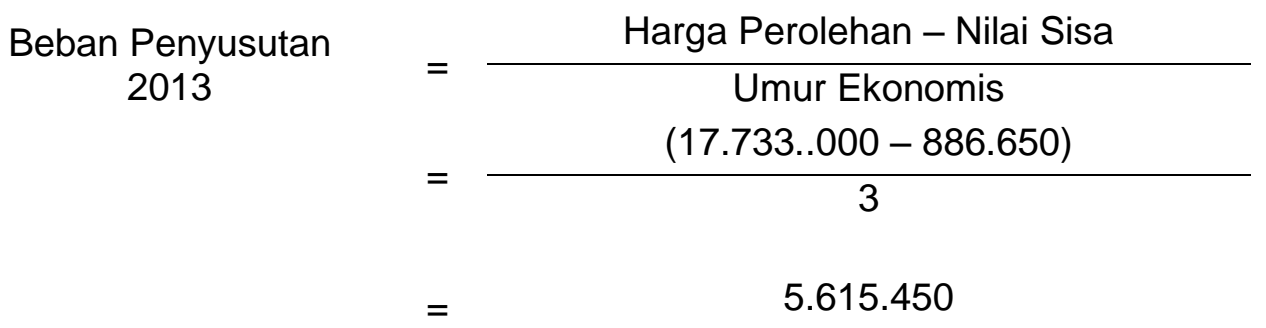

Jurnal penyusutan peralatan hotel-kain pada tahun 2013 adalah :

\begin{tabular}{|c|l|c|c|}
\hline Tgl & \multicolumn{1}{|c|}{ Akun } & Debit & Kredit \\
\hline \hline 31-Des-13 & $\begin{array}{l}\text { Beban Penyusutan-Peralatan Hotel- } \\
\text { Kain }\end{array}$ & 5.615 .450 & \\
\hline & $\begin{array}{l}\text { Akumulasi Penyusutan-Peralatan } \\
\text { Peralatan Hotel- Kain }\end{array}$ & & 5.615 .450 \\
\hline
\end{tabular}

Tabel 3.11

Beban Penyusutan Peralatan Hotel - Kain per Tahun (dalam Rupiah)

Metode Penyusutan Garis Lurus

\begin{tabular}{|c|c|c|c|c|}
\hline Tahun & $\begin{array}{c}\text { Harga } \\
\text { Perolehan }\end{array}$ & $\begin{array}{c}\text { Beban } \\
\text { Penyusutan }\end{array}$ & $\begin{array}{c}\text { Akumulasi } \\
\text { Penyusutan }\end{array}$ & $\begin{array}{c}\text { Nilai Buku } \\
\text { Akhir Tahun }\end{array}$ \\
\hline 2011 & 15.780 .000 & 4.997 .000 & 4.997 .000 & 10.783 .000 \\
\hline
\end{tabular}




\begin{tabular}{|l|l|l|l|l|}
\hline 2012 & 15.780 .000 & 4.997 .000 & 9.994 .000 & 5.786 .000 \\
\hline 2013 & 33.513 .000 & 10.612 .450 & 20.606 .450 & 12.906 .550 \\
\hline 2014 & 33.513 .000 & 5.615 .450 & 26.221 .900 & 7.291 .100 \\
\hline 2015 & 33.513 .000 & 5.615 .450 & 31.837 .350 & 1.675 .650 \\
\hline
\end{tabular}

Berdasarkan teori mengenai perhitungan beban penyusutan pada tahun pertama apabila tanggal perolehan peralatan hotel-kain terjadi antara tanggal 1 sampai dengan 15, maka perhitungan beban penyusutan dihitung dari bulan yang bersangkutan.

Maka perhitungan beban penyusutan peralatan hotel-kain untuk tahun 2011 adalah sebagai berikut :

Beban Penyusutan = Peralatan Hotel-Kain Bulan Februari 2011

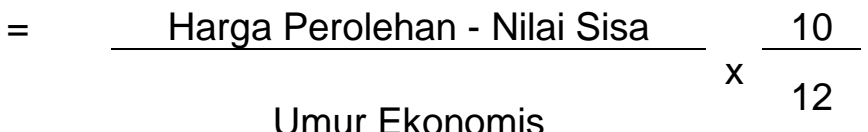
Umur Ekonomis

$$
\begin{aligned}
& =\frac{(15.780 .000-1.578 .000)}{3} \times \frac{10}{12} \\
& =3.945 .000
\end{aligned}
$$

Jurnal penyusutan peralatan hotel-kain pada tahun 2011 adalah :

\begin{tabular}{|c|l|c|c|}
\hline Tgl & \multicolumn{1}{|c|}{ Akun } & Debit & Kredit \\
\hline \hline 31-Des-11 & $\begin{array}{l}\text { Beban Penyusutan-Peralatan Hotel- } \\
\text { Kain }\end{array}$ & 3.945 .000 & \\
\hline & $\begin{array}{l}\text { Akumulasi Penyusutan-Peralatan } \\
\text { Peralatan Hotel- Kain }\end{array}$ & & 3.945 .000 \\
\hline
\end{tabular}

Perhitungan beban penyusutan peralatan hotel-kain untuk tahun 2013 adalah sebagai berikut :

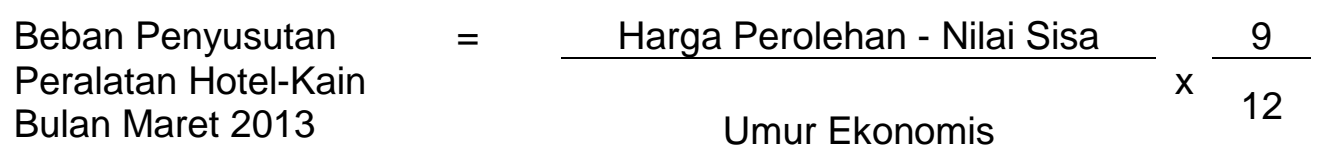




$$
\begin{aligned}
& =\frac{(8.720 .000-872.000)}{3} \times \frac{9}{12} \\
& =1.962 .000
\end{aligned}
$$

Beban Penyusutan Peralatan Hotel-Kain Bulan Mei 2013

Beban Penyusutan Peralatan Hotel-Kain Bulan Juni 2013

$$
\begin{aligned}
& =\frac{\text { Harga Perolehan - Nilai Sisa }}{\text { Umur Ekonomis }} \times \frac{7}{12} \\
& =\frac{(2.905 .000-290.500)}{3} \times \frac{7}{12} \\
& =508.375
\end{aligned}
$$

$=\quad$ Harga Perolehan - Nilai Sisa $\times \frac{6}{12}$ Umur Ekonomis

$$
\begin{aligned}
& =\frac{(6.108 .000-610.800)}{3} \times \frac{6}{12} \\
& =916.200
\end{aligned}
$$

Jurnal penyusutan peralatan hotel-kain pada tahun 2013 adalah :

\begin{tabular}{|c|l|c|c|}
\hline Tgl & \multicolumn{1}{|c|}{ Akun } & Debit & Kredit \\
\hline \hline 31-Des-13 & $\begin{array}{l}\text { Beban Penyusutan-Peralatan Hotel- } \\
\text { Kain }\end{array}$ & 3.386 .575 & \\
\hline & $\begin{array}{l}\text { Akumulasi Penyusutan-Peralatan } \\
\text { Peralatan Hotel- Kain }\end{array}$ & & 3.386 .575 \\
\hline
\end{tabular}


Tabel 3.12

Beban Penyusutan Peralatan Hotel - Kain per Tahun (dalam Rupiah)

Metode Penyusutan Garis Lurus

\begin{tabular}{|c|c|c|c|c|}
\hline Tahun & $\begin{array}{c}\text { Harga } \\
\text { Perolehan }\end{array}$ & $\begin{array}{c}\text { Beban } \\
\text { Penyusutan }\end{array}$ & $\begin{array}{c}\text { Akumulasi } \\
\text { Penyusutan }\end{array}$ & $\begin{array}{c}\text { Nilai Buku } \\
\text { Akhir Tahun }\end{array}$ \\
\hline 2011 & 15.780 .000 & 3.945 .000 & 3.945 .000 & 11.835 .000 \\
\hline 2012 & 15.780 .000 & 4.734 .000 & 8.679 .000 & 7.101 .000 \\
\hline 2013 & 33.513 .000 & 8.120 .575 & 16.799 .575 & 16.713 .425 \\
\hline 2014 & 33.513 .000 & 10.053 .900 & 26.853 .475 & 6.659 .525 \\
\hline 2015 & 33.513 .000 & 10.053 .900 & 36.907 .375 & $(3.394 .375)$ \\
\hline
\end{tabular}

\subsubsection{Penyajian Aset pada Laporan Posisi Keuangan}

Pada Win's Hotel penyajian aset tetap dikelompokkan menjadi beberapa bagian sebagai berikut :

1. Tanah

2. Bangunan Hotel

3. Kendaraan

4. Peralatan Kantor

5. Peralatan Hotel yang dibagi lagi menjadi elektronik, perabotan dan kain.

Tujuan dari pengelompokan tersebut adalah untuk mempermudah pencatatan, perhitungan biaya penyusutan dan pemahaman dalam membaca laporan keuangan terutama manajemen yang berkepentingan dalam melakukan pengendalian terhadap kegiatan operasional hotel. Untuk lebih memahami penyajian laporan posisi keuangan Win's Hotel, maka berikut format laporan posisi keuangan Win's Hotel : 
WINS HOTEL

NERACA

31 Desember 20XX

\section{ASET LANCAR}

KAS DAN SETARA KAS

Kas

Kas Kecil

BCA

TOTAL KAS DAN SETARA KAS

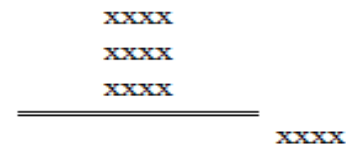

PERLENGKAPAN

Kebersihan

Hotel

TOTAL PERLENGKAPAN

PIUTANG

BIAYA DIBAYAR DIMUKA

PERSEDLAAN

Barang Dagangan

Compliment

TOTAL PERSEDIAAN

TOTAL ASET LANCAR

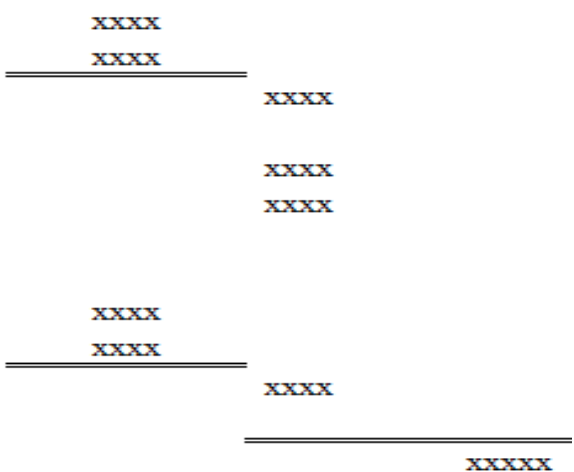

\section{ASET TETAP}

TANAH

$\operatorname{xxxxx}$

BANGUNAN

$\operatorname{xxxxx}$

Dikurangi Akumulasi Penyusutan

NILAI BUKU BANGUNAN

KENDARAAN
Dikurangi Akumulasi Penyusutan

$(\mathrm{xxxxx})$

NILAI BUKU KENDARAAAN

$(\mathrm{xxxxx})$

PERALATAN KANTOR

Dikurangi Akumulasi Penyusutan

NILAI BUKU PERALATAN KANTOR

$(\mathrm{xxxxx})$

PERALATAN HOTEL

Elektronik

Dikurangi Akumulasi Penyusutan

Perabotan

Dikurangi Akumulasi Penyusutan

Kain

Dikurangi Akumulasi Penyusutan

$\operatorname{xxxxx}$

$(\operatorname{xxxxx})$

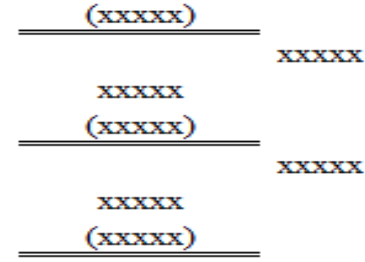

NILAI BUKU PERALATAN HOTEL

$\operatorname{xxpxx}$ 
Berdasarkan hasil tinjauan penyusun terhadap laporan posisi keuangan Win's Hotel, penyusun menyimpulkan bahwa penyajian aset tetap Win's Hotel dalam laporan posisi keuangan telah disajikan sebesar nilai buku sesuai dengan Standar Akuntansi Keuangan Entitas Tanpa Akuntabilitas Publik (SAK ETAP) Bab 15 tentang Aset Tetap.

Dalam mengukur besarnya beban penyusutan aset tetap, yang dilakukan Win's Hotel belum sesuai dengan Standar Akuntansi Keuangan Entitas Tanpa Akuntabilitas Publik (SAK ETAP) Bab 15 tentang Aset Tetap karena perhitungan beban penyusutan pada tahun perolehan belum disesuaikan berdasarkan bulan perolehan.

Win's Hotel dalam mengalokasikan biaya reparasi aset tetap dalam jumlah besar dimasukkan sebagai beban reparasi aset tetap dalam laporan laba rugi periode berjalan yang seharusnya dapat menambah umur ekonomis aset tetap dan dicatat sebagai penambah harga perolehan aset tetap.

Oleh karenanya kedua hal ini dapat menyebabkan penyajian nilai akumulasi penyusutan yang berbeda pada laporan posisi keuangan Win's Hotel. 


\section{BAB IV \\ SIMPULAN DAN SARAN}

\subsection{Simpulan}

Berdasarkan hasil tinjauan yang dilakukan oleh penyusun mengenai penyusutan aset tetap pada Win's Hotel maka dapat ditarik kesimpulan sebagai berikut :

1. Pengakuan aset tetap yang dilakukan oleh Win's Hotel telah sesuai dengan Standar Akuntansi Keuangan Tanpa Akuntabilitas Publik (SAK ETAP) Bab 15 tentang Aset Tetap, yaitu sebesar harga pembelian / harga perolehan aset tersebut ditambah biaya lain yang dikeluarkan dalam rangka mengoperasikan aset tetap tersebut.

2. Metode penyusutan yang digunakan oleh Win's Hotel terhadap aset tetap yang dimilikinya yaitu dengan menggunakan metode garis lurus (straight line method) dengan cara perhitungan nilai perolehan dikurangi nilai residu kemudian dibagi dengan umur ekonomis masing-masing aset. Penyusutan dihitung setiap akhir tahun periode berjalan, dengan pengakuan penyusutan satu tahun penuh tanpa memperhitungkan tanggal perolehan aset tetap tersebut.

3. Biaya reparasi/perbaikan dalam jumlah besar tidak dicatat sebagai penambah umur manfaat aset tetap, melainkan dibebankan pada laporan laba rugi periode berjalan.

4. Penyajian aset tetap Win's Hotel dalam laporan posisi keuangan telah sesuai dengan Pernyataan Standar Akuntansi Keuangan (PSAK) No. 16 Tahun 2012. Penyajian aset tetap yang disusutkan dalam laporan posisi keuangan dikelompokkan menurut fungsi dan umur manfaatnya, yaitu bangunan, 
peralatan kantor, dan peralatan hotel (elektronik, perabot, dan kain). Dalam laporan posisi keuangan dapat dilihat bahwa pembebanan penyusutan aset tetap adalah sama setiap tahunnya selama tidak ada penambahan atau pengurangan aset tetap.

\subsection{Saran}

Dari pembahasan yang telah dikemukakan diatas, maka penyusun memberikan saran yang sekiranya dapat bermanfaat bagi Win's Hotel terkait dengan pengakuan aset dan penyusutan aset yang dimilikinya. Adapun saran yang penulis berikan adalah sebagai berikut :

1. Pengeluaran reparasi atau perbaikan dengan jumlah besar yang dapat memperpanjang umur manfaat aset tetap sebaiknya dicatat sebagai penambah harga perolehan.

2. Pengukuran nilai penyusutan aset tetap yang dihitung setiap akhir tahun sebaiknya dihitung dari bulan perolehan agar beban penyusutan yang dialokasikan setiap tahunnya dapat disajikan secara proporsional sesuai dengan umur penggunaannya. Dalam hal ini sebaiknya perusahaan membuat kebijakan patokan waktu untuk perbaikan aset tetap yang dikapitalisasi.

3. Perusahaan diharapkan dapat meninjau atau mereview setiap akhir tahun untuk setiap aset tetap yang mengalami penyusutan untuk melihat apakah ada perubahan umur ekonomis aset disesuaikan dengan kondisi fisik aset saat periode yang bersangkutan.

4. Perusahaan sebaiknya membuat prosedur manual untuk bagian accounting yang berisi tentang kebijakan-kebijakan tertulis mengenai pengakuan dan pengukuran aset tetap yang dimiliki Win's Hotel. 


\section{DAFTAR PUSTAKA}

Al. Haryono, Jusup. 2011. Dasar-dasar Akuntansi. Cetakan 1 Edisi 7. Yogyakarta : Bagian Penerbitan Sekolah Tinggi Ilmu Ekonomi YKPN

Dwi Martani, dkk. 2012. Akuntansi Keuangan Menengah Berbasis PSAK. Buku 1. Jakarta : Salemba Empat

Efraim Ferdinan Giri. 2012. Akuntansi Keuangan Menengah 1 Perspektif IFRS. Yogyakarta : Penerbit dan Pencetak UPP STIM YKPN

Ikatan Akuntan Indonesia. 2012. Pernyataan Standar Akuntansi Keuangan No. 16 ; Aset Tetap. Penerbit Salemba Empat, Jakarta

Ikatan Akuntan Indonesia. 2011. Standar Akuntansi Keuangan Entitas Tanpa Akuntabilitas Publik Bab 15 ; Aset Tetap. Penerbit Salemba Empat, Jakarta

Ikatan Akuntan Indonesia. 2012. Pernyataan Standar Akuntansi Keuangan No. 61 ; Akuntansi Hibah Pemerintah dan Pengungkapan Bantuan Pemerintah. Penerbit Salemba Empat, Jakarta

M. Reeve, James et al. 2010. Pengantar Akuntansi Adaptasi Indonesia. Buku 2. Jakarta : Penerbit Salemba Empat

$\mathrm{Ng}$ Eng, Juan, dan Ersa Tri Wahyuni. 2012. Panduan Praktis Standar Akuntansi Keuangan. Edisi kedua. Jakarta : Penerbit Salemba Empat

Raja Adri Setiawan Surya. 2012. Akuntansi Keuangan Versi IFRS. Edisi Pertama. Yogyakarta : Graha IImu

Soemarso S. R. 2005. Akuntansi Suatu Pengantar, Buku 2 Edisi 5, Jakarta : Salemba Empat

Stice, E. Kay et al. 2009. Akuntansi Intermediate. Edisi 16 : Buku 2. Jakarta : Salemba Empat

Warren et al. 2008. Accounting Pengantar Akuntansi. Buku Satu Edisi 21, Jakarta : Salemba Empat

Mulyana, M., 2012. Faktor-faktor yang Membentuk Intensi Berwirausaha sertaPengaruhnya terhadap Perilaku dan Kinerja Pedagang Kaki Lima di Kota Bogor [tesis]. Bogor (ID): Institut Pertanian Bogor.

Safitri, H.W. and Nurendah, Y., 2013. STRATEGI PELAYANAN PADA PENJUALAN SEPEDA MOTOR HONDA PADA PT. SANPRIMA SENTOSA BOGOR. Jurnal Online Mahasiswa-Manajemen, 1 (1).

Angga, A. and Nurendah, Y., 2013. STRATEGI PROMOSI TERHADAP PENJUALAN MOTOR HONDA PADA PT. SANPRIMA SENTOSA BOGOR. Jurnal Online Mahasiswa-Manajemen, 1 (1).

Munawar, A., 2010. Analisis Nilai Tambah Dan Pemasaran Kayu Sengon Gergajian (Studi Kasus di Kecamatan Cigudeg Kabupaten Bogor).

Soelehan, A. and Sukartaatmadja, I., 2009. Pengaruh Disiplin Kerja, Lingkungan Kerja, dan Semangat Kerja terhadap Prestasi Kerja Warga SMP Perintis, Kecamatan Pancoran Mas Kota Depok. Jurnal IImiah Ranggagading (JIR), 9(1), pp.61-69.

Yanuar, D. and Rosita, I., 2013. Studi komparatif sistem bagi hasil pembiayaan mudharabah dan sistem bunga kredit pinjaman (Comparative study Mudharabah sharing system and the system interest rate loan). Jurnal IImiah Akuntansi Kesatuan, 1(3), pp.215-220.

Sutarti, E.T., Budianto, E.T. and Saesar, A., 2012. Evaluasi Atas Penerapan Pernyataan Standar Akuntansi Keuangan 101 Dalam Kaitannya Dengan Kewajaran Penyajian Laporan Keuangan Pada PT. Bank Jabar Banten Syariah. Jurnal Ilmiah Ranggagading (JIR), 12(2), pp.102-109. 
Tachyan Budianto, E., Magdalena Marpaung, A. and Kenshy, I., 2011. Penerapan Sistem Penjualan Cash Dan Credit Card Dalam Kaitannya Dengan Member Card Discount. Jurnal IImiah Ranggagading (JIR), 11(1), pp.28-35.

Kusmala, A.R., 2014. Pengaruh Penerapan PSAK No. 46 Terhadap Laporan Laba Rugi Pada Tiga Perusahaan Yang Terdaftar di BEl. Jurnal IImiah Akuntansi Kesatuan, 2(1), pp.031-046.

Sumiati, R., Murdihardjo, L. and Nurjanah, Y., 2014. TINJAUAN ATAS PRINSIP ISTISHNA Studi Kasus Pada PT. Bank BNI Syariah Kantor Cabang Bogor. Jurnal Online Mahasiswa-Manajemen, 1(2).

Murdihardjo, L. and Effendy, M., 2013. Peranan Pengendalian Intern Persediaan Barang Dagangan Dalam Menunjang Efektivitas Pengelolaan Persediaan. Jurnal Ilmiah Akuntansi Kesatuan, 1(1).

Supriyani, E. and Bintang Sahala, M., 2014. Pengaruh Tata Letak Terhadap Kepuasan Pelanggan Ritel. Jurnal IImiah Manajemen. Diakses, 22.

Rosadi, R. and Suardy, W., 2005. Analisis Kelayakan Kredit Investasi Studi Kusus Pada Bank Rakyat Indonesia Cabang Bogor. Jurnal IImiah Kesatuan (JIK), 7(2), pp.27-37.

Tobing, M.L., 2006. Kajian implementasi kebijakan manajemen berbasis sekolah pada pendidikan dasar di propinsi daerah khusus ibukota jakarta (Doctoral dissertation, Institut Pertanian Bogor).

Achmad, N. and Srihandoko, W., PENGARUH STOCK BUYBACK TERHADAP KINERJA SAHAM DAN KINERJA KEUANGAN.

Haryanti, A., Muktiadji, N. and Setiana, A., 2013. Analisis Dividen Tunai dan Earning Per Share Terhadap Tingkat Imbal Hasil Investor. 